TIER I ECOLOGICAL EVALUATION OF PROPOSED DISCHARGE OF DREDGED MATERIAL FROM OAKLAND HARBOR INTO OCEAN WATERS

D. K. Shreffler

R. M. Thom

B. E. Walls

J. Q. Word

Battelle/Marine Sciences Laboratory

Sequim, Washington

January 1994

Prepared for the

U.S. Army Corps of Engineers - San Francisco District under a Related Services Agreement

with the U.S. Department of Energy

under Contract DE-AC06-76RLO 1830

Pacific Northwest Laboratory

Richland, Washington 99352 


\section{SUMMARY}

The Water Resources Development Act of 1986 (Public Law 99-662) authorized the U.S. Army Corps of Engineers (USACE) - San Francisco District, to accommodate larger, deeper draft vessels in Oakland Inner and Outer Harbors by deepening and widening the existing navigation channel, and providing turning basins and maneuvering areas in Oakland Inner Harbor. The suitability of the resulting dredged material for disposal into ocean waters was subject to the 1977 Testing Manual, Ecological Evaluation of Proposed Discharge of Dredged Material into Ocean Waters (EPA/USACE 1977). However, the USACE voluntarily undertook the more environmentally conservative testing procedures of the Draft Testing Manual Evaluation of Dredged Material Proposed for Ocean Disposal (EPAUUSACE 1990). Post hoc analysis of the testing program has shown that Oakland Harbor sediment testing conformed to the procedures of the 1991 Testing Manual, Evaluation of Dredged Material Proposed for Ocean Disposal, (EPA/USACE 1991), known as the "Green Book."

The Green Book provides a tiered approach for testing the suitability of dredged materials through chemical, physical, and biological evaluations. The four levels of investigation, or tiers, outlined in the Green Book provide a phased approach for evaluating compliance with the limiting permissible concentration (LPC), as defined in the United States Ocean Dumping Regulations. The first level of investigation, or Tier I evaluation, is used to determine whether a decision on LPC compliance can be made on the basis of readily available information. The Tier I report primarily summarizes existing information on sediment contamination and toxicity potential, identifies contaminants of concern, and determines the need for further testing (i.e., Tiers II-IV).

To assist the USACE in determining the suitability of dredged material from Oakland Inner and Outer Harbors for ocean disposal, Battelle/Marine Sciences Laboratory(a) prepared this Tier I report based upon information and data provided by USACE. Because this Tier I report originated well after an LPC determination was made to require testing of project sediments in Tier III, the primary purpose of this report was to identify contaminants of concern (if any) in that particular dredged material. In addition, this Tier I report summarizes available information on chemical, physical, and biological characterization of the sediments in Oakland Inner and Outer Harbors.

Based on available information, significant potential sources of contamination have existed in Oakland Harbor since the turn of the century (Earth Metrics Inc., 1990). There was a general paucity of information on benthic communities, fish populations, and tissue contamination. The available data indicated that contaminants of potential concern are metals (including tributyltin),

(a) The Battelle/Marine Sciences Laboratory is part of the Pacific Northwest Laboratory, which is operated for the U.S. Department of Energy by Battelle Memorial Institute. 
available data indicated that contaminants of potential concern are metals (including tributyltin), pesticides, PCBs, and PAHs. Elevated concentrations of these compounds occurred throughout the proposed dredging area, but were greatest in the Inner Harbor. Of particular concern were elevated contaminants in the vicinity of the turning basin in the Inner Harbor. The results of this Tier I report indicated that Tier III sampling needed to be conducted under the 1990 Draft Green Book (EPAUUSACE 1990). These Tier III evaluations (Ward et al. 1993 and Kohn et al. 1992) enabled us to determine that the dredged material from isolated areas within Oakland Harbor contains contaminants that may pose an unacceptable risk to sensitive marine organisms, and may be unsuitable for unrestricted, unconfined open-ocean disposal. 


\section{ACKNOWLEDGMENTS}

This report reflects the input of many individuals in addition to the authors. We especially wish to recognize the efforts of Ray Bienert, not only for providing a rigorous technical review, but also for his assistance with the graphics. Ray was also the principal author on a report entitled, Tier I Ecological Evaluation For Phase III Channel Improvements To The John F. Baldwin Ship Channel, that served as a template for this Tier I report. Jeff Ward, Nancy Kohn, and Heather Mayhew willingly shared their knowledge of field sampling efforts in Oakland Harbor. Blythe Hartney was responsible for the formatting and text processing of the draft version of this report. Laura Gully did the final formatting and saw the report through to completion. 


\section{CONTENTS}

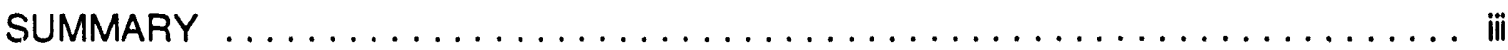

ACKNOWLEDGMENTS $\ldots \ldots \ldots \ldots \ldots \ldots \ldots \ldots \ldots \ldots \ldots \ldots$

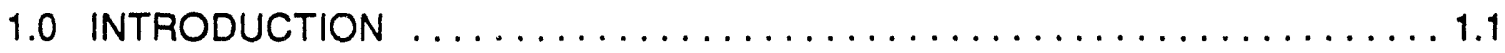

1.1 THE TIERED PROCESS FOR EVALUATING DREDGED MATERIAL AND OBJECTIVES OF THE TIER I REPORT $\ldots \ldots \ldots \ldots \ldots \ldots \ldots \ldots .1$

1.2 DESCRIPTION OF THE OAKLAND INNER AND OUTER HARBOR

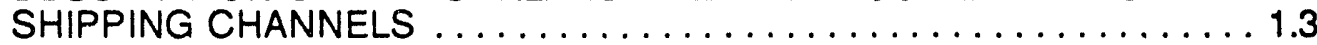

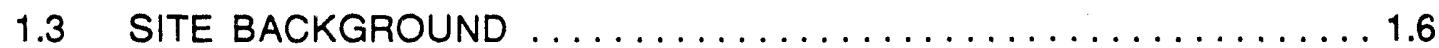

1.4 PRINCIPAL REGULATORY AUTHORITIES $\ldots \ldots \ldots \ldots \ldots \ldots \ldots .6 \ldots$ 2.0 EVALUATION OF EXISTING INFORMATION $\ldots \ldots \ldots \ldots \ldots \ldots \ldots \ldots .1$

2.1 OVERVIEW OF SEDIMENT CHEMISTRY AND SEDIMENT BIOASSAY

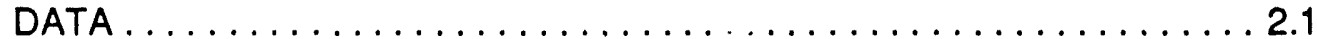

2.2 OVERVIEW OF BENTHIC INVERTEBRATE DATA . . . . . . . . 2.3

2.2.1 Benthic Invertebrate Distribution and Abundance $\ldots \ldots \ldots \ldots 2.3$

2.2.2 Benthic Invertebrate Contamination $\ldots \ldots \ldots \ldots \ldots \ldots \ldots \ldots .4$

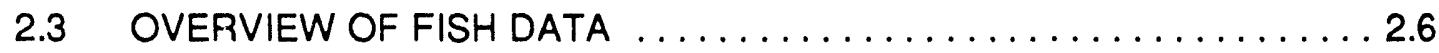

2.3.1 Fish Distribution and Abundance $\ldots \ldots \ldots \ldots \ldots \ldots \ldots \ldots \ldots$

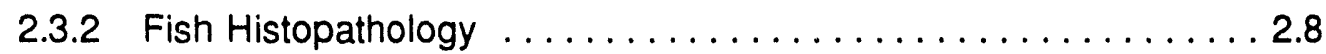

3.0 IDENTIFICATION OF CONTAMINANTS OF CONCERN $\ldots \ldots \ldots \ldots \ldots .1$

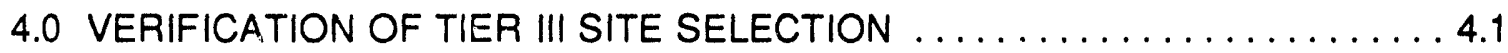

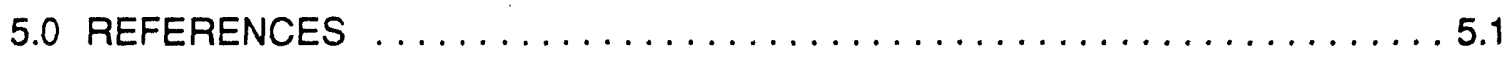

APPENDIX-MEMORANDUM FOR THE RECORD, 30 MAY $1990 \ldots \ldots \ldots \ldots \ldots .1$ 


\section{FIGURES}

1.1 Map of the San Francisco Bay Area Showing the Location of Oakland . . . . . 1.4

1.2 Map of Oakland Inner and Outer Harbors Showing the Location of the Currently Authorized Navigation Channel . . . . . . . . . . . . . . . . . . . 1.5

1.3 Map of Historical Land Uses and Industries Adjacent to the Oakland Federal Navigation Channel That May Have Contributed Contaminants to Oakland Harbor Sediments . . . . . . . . . . . . . . . . . . . . . . . . . 1.8

2.1 Locations in the Vicinity of Oakland Inner and Outer Harbors Where Infauna Samples Have Been Collected . . . . . . . . . . . . . . . . . . . . . . . 2.5

2.2 Locations in the Vicinity of Oakland Inner and Outer Harbors Where Fish Have Been Sampled . . . . . . . . . . . . . . . . . . . . . . . . . 2.7

3.1 Locations in the Vicinity of Oakland Inner and Outer Harbors Where USACE Collected Samples for Sediment Chemistry Analyses and Bioassays . . . . . . 3.4

3.2 Locations Within Oakland Inner and Outer Harbors Where Word et al. Collected Samples for Sediment Chemistry Analyses and Bioassays . . . . . . 3.7

3.3 Locations Within Oakland Inner and Outer Harbors Sampled by Word et al. That Showed Significant Toxicity, Significant Bioaccumulation, or Both . . . . . . 3.12

4.1 Sampling Stations for Tier III Testing 


\section{TABLES}

1.1 Condensed List of Historical Land Uses and Industries Adjacent to the Oakland Navigation Channel That May Have Contributed Contaminants to Oakland

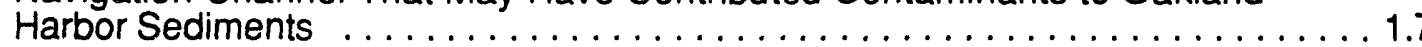

3.1 Contaminants of Concern in Oakland Inner and Outer Harbors That Have Verified Dry Weight Coricentrations $\geq 1.2 x$ Reference Sediments

3.2 Summary of the Contaminants of Concern for Sediment Samples from Oakland Inner and Outer Harbors.

3.3 Summary of the Contaminants of Concern, Toxicological Importance, Persistence in the Environment, and Propensity to Bioaccumulate for Sediment Samples from Oakland Inner Harbor $\ldots \ldots \ldots \ldots \ldots \ldots \ldots \ldots \ldots \ldots . \ldots \ldots \ldots$

3.4 Summary of the Contaminants of Concern, Toxicological Importance, Persistence in the Environment, and Propensity to Bioaccumulate for Sediment Samples from Oakland Inner Harbor . . . . . . . . . . . . . . . . . . . . . 3.9

3.5 Summary of the Contaminants of Concern, Toxicological Importance, Persistence in the Environment, and Propensity to Bioaccumulate for Sediment Samples from Oakland Inner and Outer Harbor

4.1 Stations Designated for Tier III Sampling

4.2 Analytical Chemistry Requirements for Oakland Harbor Tissue Samples 


\subsection{INTRODUCTION}

The Water Resources Development Act of 1986 (Public Law 99-662) authorized the U.S. Army Corps of Engineers (USACE) - San Francisco District, to accommodate larger, deeper draft vessels in Oakland Inner and Outer Harbors by deepening and widening the existing navigation channel, and providing turning basins and maneuvering areas in Oakland Inner Harbor. These actions will produce about 7 million cubic yards of dredged material. Proposed disposal alternatives for this dredged material include the open ocean, a confined uplands site, or San Francisco Bay.

To assist the USACE in determining the suitability of dredged materials from Oakland Inner and Outer Harbors for ocean disposal, Battelle/Marine Sciences Laboratory (MSL) prepared this Tier I report. Because this Tier I report originated well after an LPC determination was made to require testing of project sediments in Tier III, the primary purpose of this report was to identify contaminants of concern (if any) in that particular dredged material. In addition, this Tier I report summarizes available information on chemical, physical, and biological characterization of the sediments in Oakland Inner and Outer Harbors.

\subsection{THE TIERED PROCESS FOR EVALUATING DREDGED MATERIAL AND OBJECTIVES OF THE TIER IREPORT}

Technical guidance for evaluating the suitability of dredged material for ocean disposal is provided in the 1991 Testing Manual (EPA/USACE 1991), known as the Green Book. Suitability criteria presented in the Green Book are based on the biological testing requirements of the 1977 Ocean Dumping Regulations. The Green Book provides a tiered approach for testing the suitability of dredged materials through chemical, physical, and biological evaluations.

The four levels of investigation, or tiers, outlined in the Green Book provide a phased approach for evaluating compliance with the limiting permissible concentration (LPC), as defined in the United States Ocean Dumping Regulations. The LPC for the liquid-phase concentration of dredged material in the water column is the concentration that, after allowing for initial mixing, does not exceed applicable marine water-quality criteria or a toxicity threshold of 0.01 of the acutely toxic concentration. The first level of investigation, or Tier I evaluation, is used to determine whether a decision on LPC compliance can be made on the basis of readily available information. The Tier I report primarily summarizes existing information on sediment contamination and toxicity potential, identifies contaminants of concern, and determines the need for further testing (i.e., Tiers II-IV).

The goal of the information-gathering phase of a Tier I evaluation is to compile all reasonably available information for use in assessing the potential for contaminant-associated 
impacts following ocean disposal of the proposed dredged material. Specific guidelines have not been established for conducting Tier I evaluations, and to date only one other Tier I evaluation has been conducted in San Francisco Bay (Bienert et al. 1992). The Green Book recommends the following as potential sources of information:

1. The available results of prior physical, chemical, and biological tests of the material proposed to be dumped

2. The available results of prior field monitoring studies of the proposed material to be dumped (e.g., physical characteristics, organic-carbon content, and grain size)

3. The available description of the source(s) of the contaminants contained in the proposed material to be dumped, which would be relevant for identifying potential contaminants of concern

4. The existing data in U.S. Environmental Protection Agency (EPA) or USACE files or otherwise available from public or private sources; examples of potential sources include:

- Selected Chemical Spill Listings (EPA)

- Pesticide Spill Reporting System (EPA)

- Pollution Incident Reporting System (U.S. Coast Guard)

- Identification of In-Place Pollutants and Priorities for Removal (EPA)

- Hazardous waste sites and management facilities reports (EPA)

- USACE studies of sediment pollution and sediments

- Federal STORET, BIOS, CETIS, and ODES computer databases (EPA)

- Water and sediment data on major tributaries (U.S. Geological Survey)

- National Pollutant Discharge Elimination System (NPDES) permit records

- CWA 404(b)(1) evaluations

- Pertinent and applicable research reports

- Marine Protection, Research, Sanctuaries Act (MPRSA) 103 evaluations

- Port authorities

- Colleges/Universities.

The next stage of the Tier I evaluation involves comparing information on the proposed dredged material to the three criteria in 40 CFR 227.13(b) that allow exclusion from further testing. Dredged material meeting one or more of the criteria listed below is considered environmentally acceptable for unrestricted, unconfined ocean dumping without further testing:

1. Dredged material is composed predominantly of sand, gravel, rock, or any other naturally occurring bottom material with particle sizes larger than silt, and the material is found in areas of high current or wave energy such as streams with large bed loads or coastal areas with shifting bars and channels; or

2. Dredged material is for beach nourishment or restoration and is composed predominantly of sand, gravel, or shell with particle sizes compatible with material on the receiving beaches; or

3. When: (i) the material proposed for dumping is substantially the same as the substrate at the proposed disposal site; and (ii) the site from which the material proposed for dumping is to be taken is far removed from known existing and historical sources of pollution so as to provide reasonable assurance that such material has not been contaminated by such pollution. 
If none of the exclusionary criteria is met, the LPC is evaluated based on available data on the proposed dredged material. This data must include an analysis of the toxicity and bioaccumulation potential of both the dredged material and reference sediments. If existing information is insufficient to determine whether the Water Quality Criteria (WQC) or $1 \%$ of the $L C_{50}$ will be exceeded in the water column following the initial mixing period, then the evaluation process moves to Tier 11.

Tiers II-IV represent increasingly more comprehensive levels of analysis involving sediment testing. Tier II consists of a model to evaluate marine WQC compliance and estimate the potential for benthic impact. Tier III consists of bioassays and bioaccumulation tests to determine if the potential exists for the dredged material to have an unacceptable impact. Tier IV consists of bioassays and bioaccumulation tests to determine the long-term effects of exposure to dredged material. The level of testing required for a project is based on the degree of contamination expected from the sediments within a project area.

This Tier I report summarizes the existing information on chemical, physical, and biological characterization of the sediments in Oakland Inner and Outer Harbors and identifies contaminants of concern. In addition, this report provides justification for the selection of sites that were subjected to Tier III sediment testing.

\subsection{DESCRIPTION OF THE OAKLAND INNER HARBOR AND OUTER HARBOR SHIPPING CHANNELS}

In 1874, the USACE began construction of Oakland Inner Harbor, located on the eastern shoreline of central San Francisco Bay in Alameda County, California (Figure 1.1). This project consisted of widening and deepening San Antonio Creek channel to -20 ft mean lower low water (MLLW) to accommodate ships. The channel was completed in 1883. Dredged material was first disposed of in deep water within San Francisco Bay, but later pumped onto adjacent marshes. Maintenance dredging of the navigation channel has continued to the present, in addition to construction and maintenance of slips and berthing areas.

Currently, the entrance channel into the Oakland Outer Harbor is authorized to $-35 \mathrm{ft}$ MLLW over an area $600-800 \mathrm{ft}$ wide and $9000 \mathrm{ft}$ long (USACE 1990a) (Figure 1.2). The main channel and turning basin of the Outer Harbor is authorized to $-34 \mathrm{ft}$ MLLW over an area $600-900 \mathrm{ft}$ wide and $8000 \mathrm{ft}$ long. The Oakland Inner Harbor main channel is authorized to $-35 \mathrm{ft}$ MLLW over an area $275-800 \mathrm{ft}$ wide and $37,000 \mathrm{ft}$ long. The North Channel of the Inner Harbor is authorized to $-25 \mathrm{ft}$ MLLW over an area $300 \mathrm{ft}$ wide and $6000 \mathrm{ft}$ long. According to the longterm management strategy (USACE 1990a), the recommended plan for navigation channel improvements includes: 1) deepening approximately 4 miles of the Inner Harbor channel between the entrance channel and Clay Street from a currently authorized water depth of $-35 \mathrm{ft}$ 


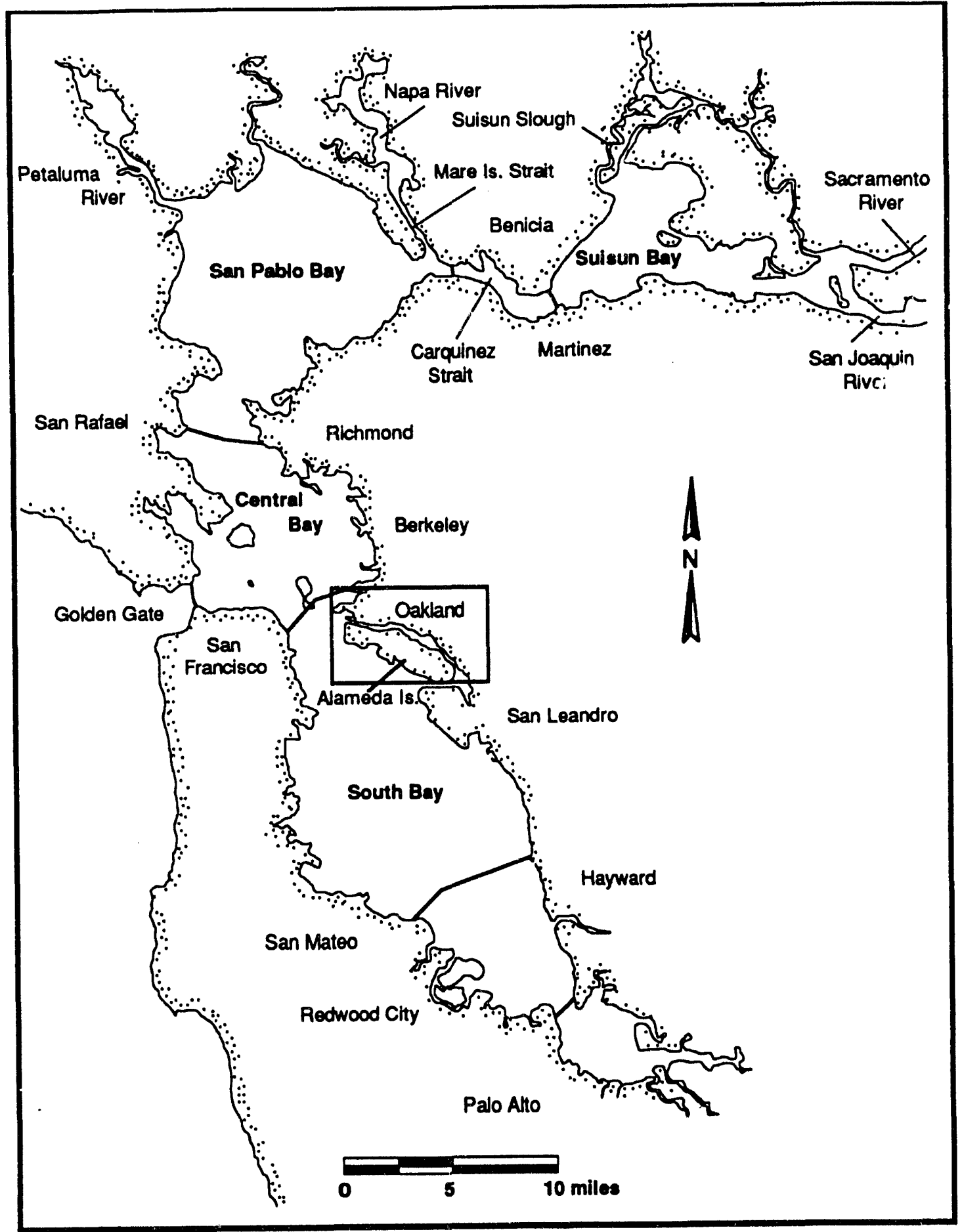

FIGURE 1.1. Map of the San Francisco Bay Area Showing the Location of Oakland. The Oakland Harbor Area Inside the Box is Shown in Greater Detail in Figure 1.2. 


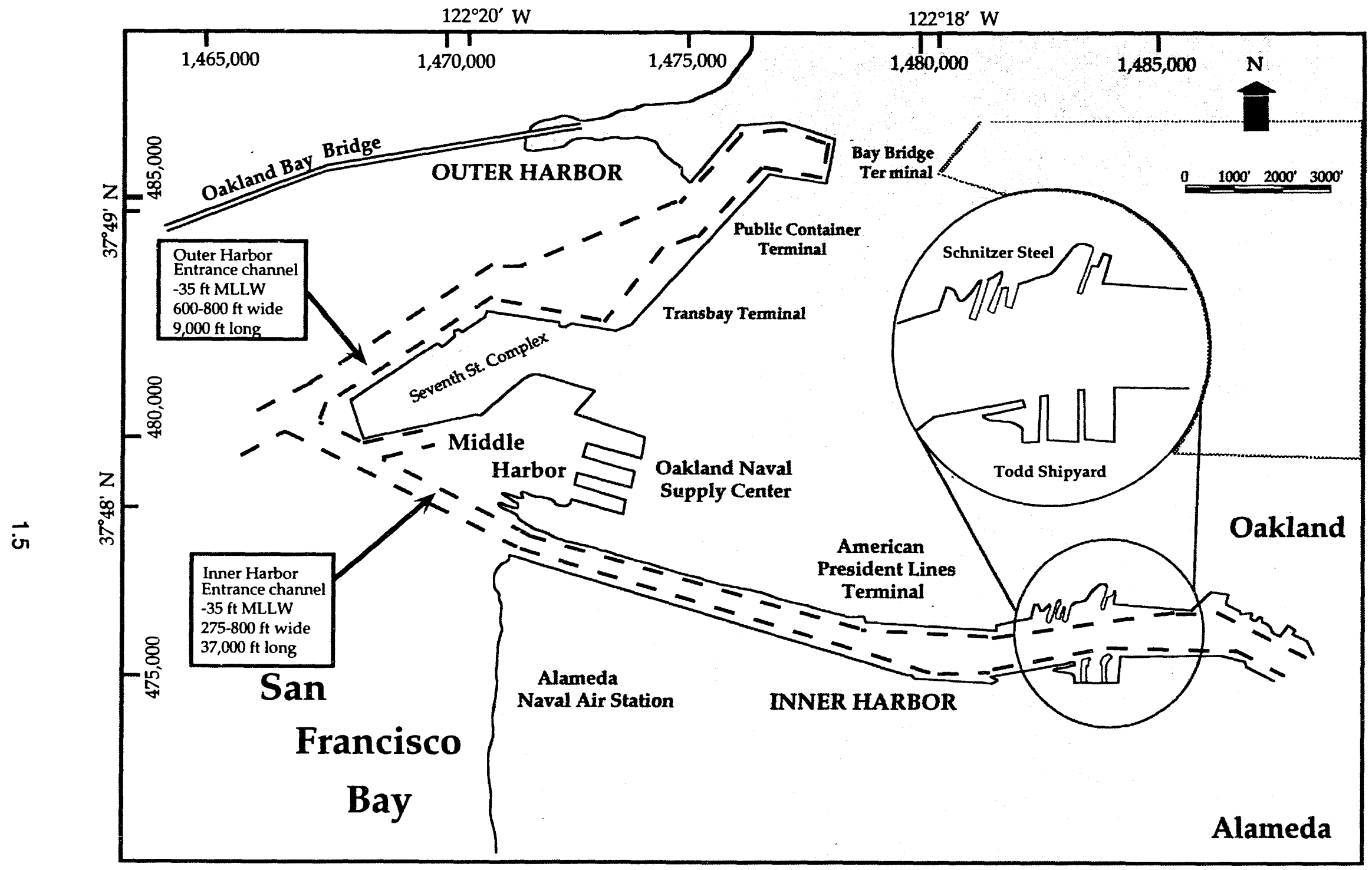

FIGURE 1.2. Map of Oakland Inner and Outer Harbors Showing the Location of the Currently Authorized Navigation Channel 
MLLW to $-42 \mathrm{ft}$ MLLW (with a $-2-\mathrm{ft}$ overdepth), 2) deepening 3.4 miles of the Outer Harbor from a currently authorized water depth of $-35 \mathrm{ft}$ MLLW to $-42 \mathrm{ft} \mathrm{MLLW} \mathrm{(with} \mathrm{a} \mathrm{-2-ft} \mathrm{overdepth),} \mathrm{and} \mathrm{3)}$ supplying the harbor with adequate turning basins and berthing areas. The navigation channels will also be widened at their entrances and at various other locations.

\subsection{SITE BACKGROUND}

Earth Metrics Inc. (1990), reported on the history of land use and industrial activity in the vicinity of Oakland Harbor. Shipping was conducted in creeks and inlets throughout the Oakland area in the 1850s. Major shipping activities involved lumber exportation and cattle hide distribution. West of Lake Merritt Slough, the land consisted primarily of undeveloped marshlands. In 1853, in order to accommodate ferry service from Oakland to San Francisco, dredging was initiated (Earth Metrics Inc. 1990). Ten years later, ferry service was begun from the end of a 3/4-mile-long wharf extending out from the end of 7th Street toward Yerba Buena Island. This wharf also accommodated a railway to service the shipping activities.

Extensive development of the rail system, including switching and maintenance yards, warehouses, and industries, occurred during the late 1800s. The Central Southern Pacific Railroad, located along the wharf, encompassed car and engine building and repair shops, a creosoting plant, shipyards, and bridge construction industries.

Industrial development along the shores of the canal and adjacent areas began in earnest in the early 1900s. The types of industries and other facilities that may have been sources of contaminants to the waterway include ship building and repairing, lumber and creosoting, paint production, pesticide storage, foundries, light and power production, coal distillation, and petroleum refineries. In addition, sewage and stormwater were discharged in several places within the navigation channel. A list of potentially hazardous industries in the vicinity of the navigation channel that may have contributed contaminants to Oakland Harbor sediments is provided in Table 1.1 (Earth Metric Inc. 1990). The locations of the industries listed in Table 1.1 are shown in Figure 1.3.

\subsection{PRINCIPAL REGULATORY AUTHORITIES}

This section provides a brief introduction to the principal government agencies and legislation responsible for regulating water quality impacts to the San Francisco Estuary. A more thorough review of the evolution of environmental policies affecting the Estuary and the specific jurisdiction of each government agency may be found in Davis et al. (1991). 
TABLE 1.1. Condensed List of Historical Land Uses and Industries Adjacent to the Oakland Navigation Channel That May Have Contributed Contaminants to Oakland Harbor Sediments (Earth Metrics Inc. 1990)

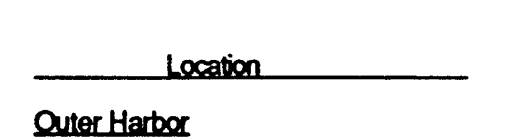

\begin{tabular}{|c|c|}
\hline $\begin{array}{l}\text { Codes in } \\
\text { Fioure } 1.3\end{array}$ & $\begin{array}{c}\text { Shipping' } \\
\text { Shipbuildng }\end{array}$ \\
\hline 22 & $x$ \\
\hline 30 & $x$ \\
\hline $\mathbf{2}$ & \\
\hline 13 & \\
\hline 11 & \\
\hline 10 & \\
\hline 7 & $x$ \\
\hline 2 & $x$ \\
\hline $107 / 106 / 105$ & $x$ \\
\hline $104 / 103$ & $x$ \\
\hline $102 / 101 / 100$ & $x$ \\
\hline $\boldsymbol{9}$ & $x$ \\
\hline 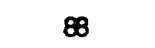 & \\
\hline 85 & $x$ \\
\hline $81 / 79$ & $x$ \\
\hline 72 & \\
\hline 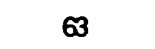 & \\
\hline 6058 & $x$ \\
\hline $56 / 56 a$ & $x$ \\
\hline 5 & \\
\hline $47 / 43 / 35$ & $x$ \\
\hline 34 & $x$ \\
\hline
\end{tabular}

\begin{tabular}{|c|c|c|c|c|c|c|}
\hline $\begin{array}{l}\text { Shipping' } \\
\text { Shipbuilding }\end{array}$ & $\begin{array}{l}\text { Petroleum } \\
\text { Products }\end{array}$ & Motals & $\begin{array}{l}\text { Building } \\
\text { Materials }\end{array}$ & $\begin{array}{l}\text { Food } \\
\text { Processing }\end{array}$ & Gatage & Solvents \\
\hline
\end{tabular}

Outer Harbor Berth 12

Outer Harbor Berth 10

Outer Harbor Berth 6

Water, W. of Container Berth 4

OH Container Berth 2

OH Berth 1, Niemeth Towing

Outer Harbor reminal expansion

7th St. Public Container Terminal

\section{Inner Harbor}

Naval Air Station

Alameda Gateway Project

Naval Supply Center

¿ Unknown: Amy?

Boatel, Port fireboat station

Clay St. Dock and Warehouse

Grove St. Pier, Howard Terminals

Howard Terminals

Howard Terminals

Schnitzer Steel

Middle Harbor Terminal

Middle Harbor Termina!

Middle Harbor Terminal

Naval Supply Depot

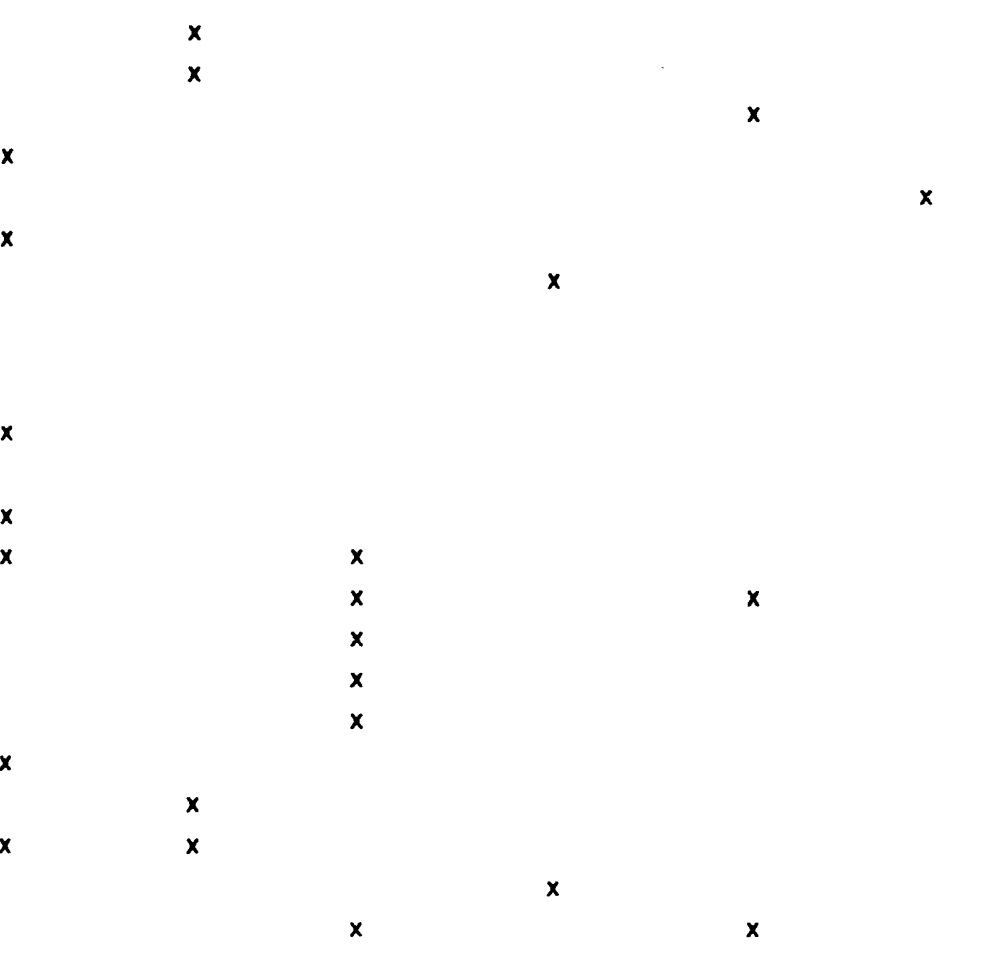




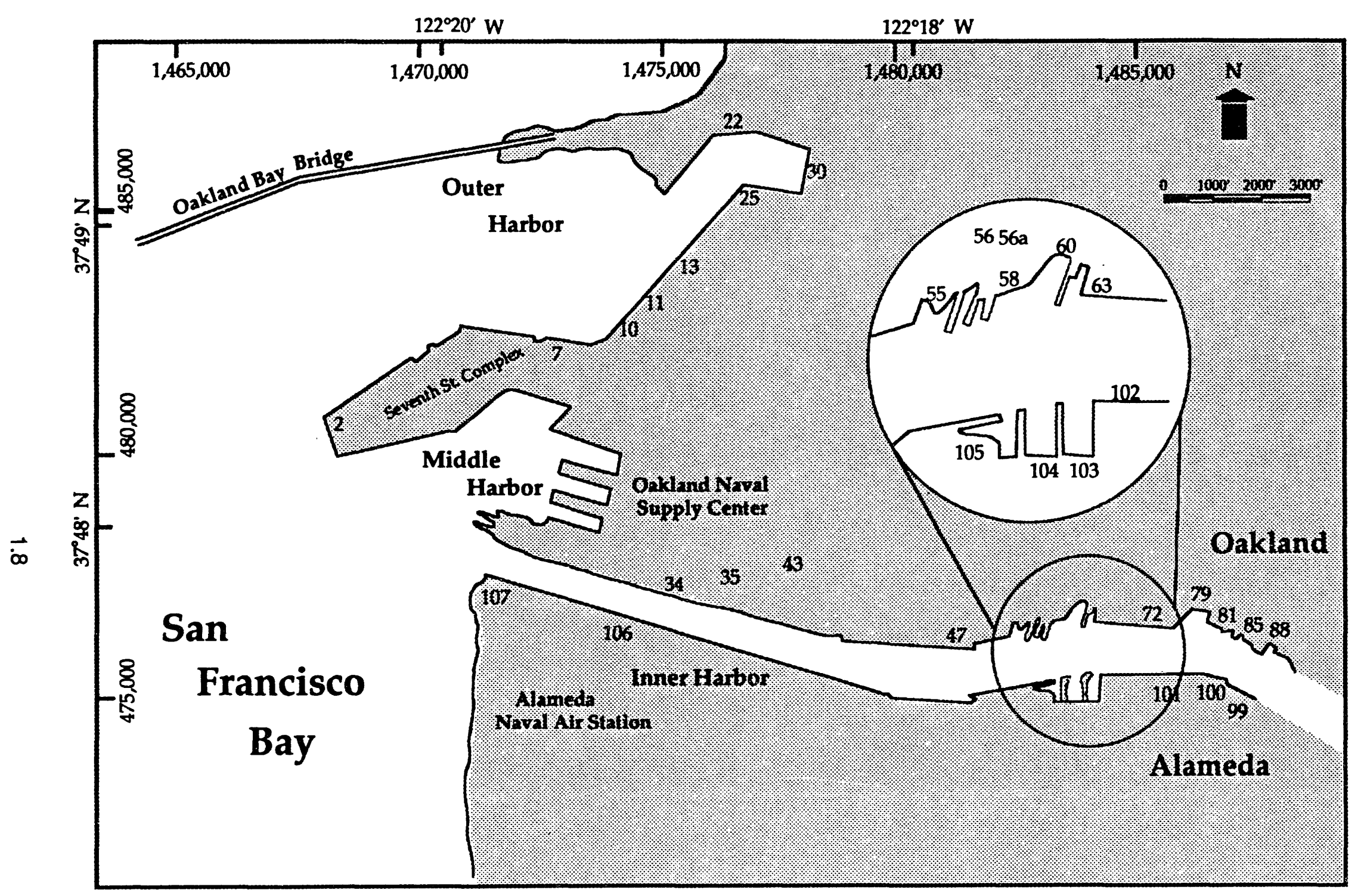

FIGURE 1.3. Map of Historical Land Uses and Industries Adjacent to the Oakland Federal Navigation Channel That May Have Contributed Contaminants to Oakland Harbor Sediments (Key to Site Designation Codes is Provided in Table 1.1) 
The U.S. Environmental Protection Agency (EPA) and the California Regional Water Quality Control Board (CRWQCB) are the principal authorities regulating sources of pollution to the San Francisco Estuary. This authority is derived primarily from the 1972 (and subsequent) amendments to the Federal Water Pollution Control Act (or Clean Water Act). The EPA administers the provisions of the Clean Water Act (CWA), and CRWQCB implements them. The SWRCB shares authority for the implementation of both the CWA and Porter-Cologne Water Quality Control Act with nine Regional Water Quality Control Boards. The San Francisco Estuary lies within the jurisdiction of two Regional Boards, the San Francisco Bay Regional Water Quality Control Board (SFBRWQCB) and the Central Valley Regional Water Quality Control Board (CVRWQCB). The Regional Water Quality Control Boards conduct planning, permitting, and enforcement activities under the direction and guidance of the SWRCB.

The 1972 CWA established the National Pollutant Discharge Elimination System (NPDES) program to regulate the discharge of municipal and industrial wastewater. The CRWQCB and nine Regional Water Quality Control Boards manage the NPDES program for the State of California. The NPDES program requires all municipal and industrial facilities to obtain permits that specify allowable limits for pollutant levels in effluents. Recently proposed regulations also require NPDES permits for stormwater discharges associated with certain industrial and commercial activities, and for municipal storm sewers serving populations greater than 100,000 (Gunther et al. 1990).

The USACE has primary responsibility for maintaining navigable waters throughout the United States. The River and Harbor Act of 1899 requires the USACE to issue permits for all dredging activities affecting navigable waters. The 1969 National Environmental Policy Act (NEPA) further requires assessment of each permit application for potential environmental impacts, and the preparation of an environmental impact statement (EIS) when proposed activities are likely to result in significant environmental effects, or there is a finding of no significant impact (FONSI) for proposed activities that are not likely to have significant environmental effects. Dredging conducted by the USACE is not covered by permits, but is subject to the same environmental reviews as permitted dredging projects, including water quality certification by the Regional Water Quality Control Boards. The 1972 Marine Protection, Research, and Sanctuaries Act (MPRSA) gives the USACE permitting authority over the transportation of dredged material for disposal into coastal waters and the open ocean. The Regional Water Quality Control Boards also have independent authority, under the California Water Code, to regulate discharges of dredged material. Additionally, the Regional Water Quality Control Boards can require appropriate biological and chemical tests necessary to assess the potential for dredging activities to violate water quality objectives. 
The San Francisco Bay Conservation and Development Commission (BCDC) was created by the 1965 State McAteer Act and has permitting authority for dredging and filling activities within the Bay. The BCDC derives additional authority from the 1972 federal Coastal Zone Management Act (CZMA). The BCDC's policies concerning dredging activities are outlined in the San Francisco Bay Plan (Bay Plan). The Bay Plan was the first coastal zone management program in the nation to be certified by the CZMA. The BCDC is charged with reviewing all proposed federal activities and licenses or permits for compliance with the Bay Plan.

The State Lands Commission (SLC) administers public trust lands in tidal and submerged areas and in coastal waters to within a 3-mile state territorial limit. Dredging and filling activities on lands within SLC jurisdiction require prior written authorization. Authorization is provided in the form of a dredging permit or a mineral extraction lease (contingent upon compliance with the requirements of the California Environmental Quality Act).

Other government agencies such as the U.S. Fish and Wildlife Service (USFWS), National Marine Fisheries Service (NMFS), U.S. Coast Guard (USCG), California Department of Fish and Game (CDFG), and the California Coastal Commission (CCC) have specific authority over dredging and filling activities and routinely participate in the review of dredging permits. The USFWS is authorized under the 1958 Fish and Wildlife Coordination Act (FWCA) to review federally funded, licensed, or permitted projects that potentially impact fish or wildlife habitat. The USFWS has additional authority under the Endangered Species Act when endangered or threatened species are involved. The NMFS is authorized under the CWA and NEPA to review federal projects that may affect marine, estuarine, or anadromous fisheries. The USCG reviews permit applications to assure that dredging activities will not impair the safe and orderly flow of maritime traffic. The USCG also assists the USACE in monitoring the activities of disposal barges throughout the Estuary using their "Vessel Traffic System." The CCC has authority to review the designation of ocean disposal sites and ensures that federally authorized activities are consistent with the California Coastal Management Program.

The National Estuary Program (NEP), established in 1987 under the federal Water Quality Act (WQA) and managed by the EPA, is dedicated to the protection of our national estuaries. The purpose of NEP is to identify nationally significant estuaries threatened by pollution, development, or overuse, and to promote preparation of comprehensive management plans to ensure their ecological integrity. The San Francisco Estuary Project (SFEP) was established in 1988 as part of the NEP. The SFEP has addressed a number of management issues in the Bay-Delta region, including the decline of biological resources, increased pollutants, freshwater diversion and altered flow regimes, increased waterway modification, and intensified land use. The SFEP is composed of representatives from the public and private sector and all levels of government, including elected officials from each of the Bay-Delta counties. Studies 
conducted through the SFEP have been summarized in a series of six "Status and Trends" reports: Wetlands and Related Habitats, Aquatic Resources, Wildlife, Pollutants, Dredging and Waterway Modification, and Land Use and Population.

The Aquatic Habitat Institute (AHI) is an independent, nonprofit corporation whose goal is to evaluate the present and potential future effects of pollution on the Bay-Delta. The AHI is directed by a ten-member Board of representatives from industrial and municipal dischargers, state and federal agencies, academic institutions, and the public. The AHI is funded through a variety of state and federal agencies, discharger associations, local governments and foundations, as well as membership fees and contributions. The AHI often works jointly with the SFEP on water quality issues and has published a number of reports on the loading, fate, and effects of contaminants in the Bay-Delta (Davis et al. 1991; Gunther et al. 1987; Phillips 1987).

Local governments and organizations representing specific interest groups also take an active role in the formation and review of regulatory policies established by the government agencies. For instance, two major associations, the Bay Area Dischargers Association (BADA) and the Bay Area League of Industrial Associations, represent the interests of dischargers to the Estuary in public review processes. Various environmental groups, including the Audubon Society, Citizens for a Better Environment, the Oceanic Society, the Pacific Coast Federation of Fishermen Association, the Save San Francisco Bay Association, and United Anglers provide comments on proposed activities having potential environmental impacts. The U.S. Department of Defense, port authorities, yachting associations, and other groups that depend sn dredging to maintain navigable waterways also comment on dredging management decisions and policies. 


\subsection{EVALUATION OF EXISTING INFORMATION}

This section contains the evaluation of all reasonably available information to determine the potential for contamination of surrounding harbor sediments that may be dredged. Samples collected in the vicinity of Oakland Harbor have been analyzed for sediment contamination, benthic invertebrate contamination, fish tissue contamination and diseases, and bioaccumulation.

\subsection{QVERVIEW OF SEDIMENT CHEMISTRY AND SEDIMENT BIOASSAY DATA}

Data on sediment chemistry and sediment bioassays from areas in the vicinity of Oakland Harbor are available. Much of the work has been conducted in various berths and channels within the Inner and Outer Harbors in order to evaluate dredged material (USACE 1979). The most comprehensive summary of this early information was compiled by Long et al. (1988), who listed 20 studies containing data on concentrations of contaminants in San Francisco Bay. Eighteen of these studies contained data on selected trace metals (i.e., mercury $(\mathrm{Hg})$, cadmium $(\mathrm{Cd})$, copper (Cu), lead (Pb), chromium ( $\mathrm{Cr}$ ), silver (Ag)); five studies reported concentrations of polynuclear aromatic hydrocarbons (PAHs); and thirteen studies reported concentrations of DDT and polychlorinated biphenyls (PCBs). Long and Markel (1992) summarized sediment contamination and sediment bioassay data from 60 studies conducted throughout San Francisco Bay, some of which contained data specific to Oakland Harbor or the project area. However, many of these studies collected data in a sporadic and inconsistent mantrer, and thus the average values for contamination in sediments presented by Long and Markel (1992) should not be viewed as representative of the project area.

Studies relevant to this Tier I report include Chapman et al. (1986), Shopay and Bruggers (1988), Power and Chapman (1988), and McPherson et al. (1989). The rsbjective of Chapman et al. (1986) was to assess whether the Sediment Quality Triad approach in San Francisco Bay could be used to augment the field measurements of the NOAA National Status and Trends (NS\&T) program. The Sediment Quality Triad approach consisted of coincident measurements of sediment contamination by chemical analyses, sediment toxicity through performance of laboratory sediment bioassays, and infaunal community structure by collection of benthic macroinfauna data. Synoptic measurements of the Sediment Quality Triad components were taken at three sites in San Francisco Bay: Islais Waterway, a site near Oakland Inner Harbor, and in San Pablo Bay.

The results supported the initial hypothesis that no individual component of the Sediment Quality Triad can be used to predict the results of the measurement of the other components. The Sediment Quality Triad provided an integrated assessment of pollution-induced degradation that could not have been done with any of its separate components. Islais Waterway was the 
most pollution-degraded site. Using a composite index developed from the Sediment Quality Triad components, Islais waterway was considered 58 times more degraded than the San Pablo Bay site, the site most removed from direct anthropogenic influences. The Oakland site was 1.4 times more degraded than the San Pablo Bay site. On the basis of this study, the Sediment Quality Triad approach was recommended for incorporation into the NOAA NS\&T Program. Specific recommendations for the presentation and use of the Sediment Quality Triad approach are provided in Section 4.4 of Chapman et al. (1986).

Shopay and Bruggers (1988), collected sediments from six areas near the Naval Supply Center Piers 4 and 5 in Oakland Middle Harbor. These sediments were then evaluated as a precursor to obtaining disposal permits necessary for the proposed renovation of the Oakland Naval Supply Center (NSC). To address both open-ocean and in-bay disposal permit requirements, both suspended-particulate-phase and solid-phase bioassays were performed on NSC material. Suspended-particulate-phase bioassays used Citharichthys stigmaeus (speckled sanddabs), Acanthomysis sculpta (mysid shrimp), and larvae of Mytilus edulis (bay mussels). Solid-phase bioassays used A. sculpta, Macoma nasuta (bent-nose clams), and Nephtys caecoides (polychaete worms) as test organisms.

In the suspended-particulate-phase bioassays, all of the NSC sediments caused significant sanddab and mysid mortality and significantly reduced normal development of the bay mussel larvae. None of the sediments caused significant mortality to any test species in the solidphase bioassays. Bulk sediment chemistry results showed slight elevations of oil and grease and of mercury $(\mathrm{Hg})$, nickel $(\mathrm{Ni})$, and zinc $(\mathrm{Zn})$. It was not clear what sediment component was responsible for the observed mortalities in the suspended-particulate phase bioassays.

Power and Chapman (1988) performed chemical analyses and bioassay testing of sediment collected from Oakland Outer Harbor to assist in determining whether disposal of dredged material was in compliance with Section 404 of the Clean Water Act and Public Notice 87-1. Bivalve larvae bioassays were performed on sediment proposed for dredging from six sections of Oakland Outer Harbor, extending from the bar channel (Section 1) to the inner reach of the Outer Oakland Harbor (Section 6) and from four sections of the Alcatraz Island reference site (Sections A, B, C, and D). The authors provide summary tables of detected parameters in the sediments ( 10 metals, 3 organics, 1 phenol, 14 PAHs, 3 chlorinated pesticides, and 2 PCBs) and grain-size analysis.

Power and Chapman (1988) reported that sediment from the Oakland Outer Harbor had higher concentrations than the Alcatraz Island reference sediment for all detected metals (except cadmium and chromium), chlorinated pesticides, and PCBs. Oakland Outer Harbor sediments aiso had a higher percentage of total organic carbon than the reference sediments, and nearly 2.5 
times greater concentrations of oil and grease. In contrast, the Alcatraz Island reference site had higher levels of total chlorinated phenol and PAHs than Oakland Outer Harbor.

McPherson et al. (1989) collected sediment samples for bulk chemical analyses and bivalve larvae bioassays from six sections in Oakland Inner Harbor, six sections in Oakland Outer Harbor, and two sites in the Alcatraz Island disposal area. This report summarizes parameters detected in the sediment (10 metals, 2 organics, 4 phenols, 15 PAHs, 2 chlorinated pesticides, and 1 PCB), grain-size analysis, and oyster larvae sediment toxicity data.

McPherson et al. (1989) found that sediment from the Oakland Inner Harbor had higher concentrations than the Alcatraz Island disposal site sediment for total organic carbon (TOC), chlorinated pesticide and PCBs, oil and grease, 11 of the 15 detected PAHs, and all detected metals except chromium. Alcatraz Island disposal site sediment had lower levels of phenols than the Oakland Inner Harbor sediment, with the exception of total chlorinated phenol.

Oakland Outer Harbor sediment had higher concentrations of TOC, chlorinated pesticide and PCBs, oil and grease, phenols, and all detected metals (except $\mathrm{Cd}$ and $\mathrm{Cr}$ ) when compared to the Alcatraz Island disposal site sediment.

\subsection{OVERVIEW OF BENTHIC INVERTEBRATE DATA}

\subsubsection{Benthic Invertebrate Distribution and Abundance}

The United States Bureau of Fisheries steamer "Albatross" conducted biological surveys of San Francisco Bay from 1912 through 1913. Schmitt (1921) summarized all of the trawl survey data. Decapod crustaceans were collected within Oakland Inner Harbor on April 8, 1912, using a 19-in. boat dredge and 3-ft Tanner trawl. The following species were captured: >50 Crangon franciscorum, 47 Crangon nigricauda, 11 Hemigrapsis oregonensis, 3 Pagurus ochotensis, 2 Cancer magister, 2 Spirontocaris cristata, and 1 Callianassa longimana.

Hopkins (1986) summarized the benthic invertebrate data from San Francisco Bay for 42 studies conducted through 1982, and presented the distribution of the 24 most common infauna taxa along with symbols representing species density categories (eg., 1-100, 101-1000 individuals $\mathrm{m}-2$ ). There appeared to be no unusual occurrences or elevated densities of pollution indicator species (e.g., Capitella capitata) in the vicinity of Oakland Harbor. Furthermore, the densities of pollution sensitive taxa (e.g., microcrustacea) in the samples collected in Oakland Harbor or San Leandro Bay were comparable to the densities found in the remainder of San Francisco Bay.

Of the 42 studies Hopkins (1986) reviewed, only one (Leighton and Associates 1978) contained data from Oakland Harbor (11 sites located within Oakland Outer Harbor and 1 site within Oakland Inner Harbor). The study found that the community at the upper (landward) end 
of the Outer Harbor had decreased species diversity and species evenness relative to the sites closer to the entrance channel. The authors attributed these decreases to normal seasonal changes and annual maintenance dredging. According to Edward Long. Senior Oceanographer, NOAA collected additional samples of infaunal communities in Oakland Harbor and elsewhere in February 1987. Although the samples were processed, the data has not been fully analyzed or published. Figure 2.1 shows the locations of all known sites within Oakland Inner and Outer Harbors where infauna samples have been collected.

Nichols (1979) concluded that the major factors controlling infaunal community structure in San Francisco Bay were natural perturbations such as major fluctuations in salinity, biotic disturbances, and abiotic disturbances such as seasonally increased sediment loads and wind-generated wave disturbance. Anthropogenic influences were difficult to partition from natural influences. The conditions in San Francisco Bay favor species that rapidly colonize benthic environments. Several exotic species, which are adapted for rapid colonization of disturbed areas, have also invaded San Francisco Bay and are now dominant in many areas. According to Edward Long of NOAA, infaunal community structure (i.e., densities, numbers of taxa) in samples collected throughout San Francisco Bay followed trends seen in sediment contamination (Long et al. 1988). However, heavily impacted communities (i.e., low number of species, the absence of microcrustacea) were not evident from their collections.

\subsubsection{Benthic Invertebrate Contamination}

Long et al. (1988) summarized chemical contamination data for benthic invertebrates in San Francisco Bay. The 33 studies cited by the authors included data on concentrations of trace metals, PAHs, DDT, and PCBs in mussels, oysters, clams, crab, and shrimp. In 1984, NOAA began a nationwide comprehensive study under their NS\&T program, termed Biological Surveillance and Mussel Watch, to determine long-term trends in contamination of coastal sediments and biota. The California Mussel Watch program has sampled San Francisco Bay mussels (Mytilus edulis) or coastal mussels (Mytilus californianus) at 32 sites in San Francisco Bay. These mussels were either resident or transplanted to the sites from reference areas. Sampling has been conducted as part of this program since 1979. Based on the data presented in Long et al. (1988), maximum concentrations of $\mathrm{Cd}, \mathrm{Pb}$, and $\mathrm{Ag}$ in mussels from the Oakland Harbor NS\&T site were at least two times greater than concentrations in Tomales Bay mussels. Concentrations of $\mathrm{Cd}, \mathrm{Pb}$, and $\mathrm{Cr}$ in the tissue of Japanese littleneck clams, Tapes japonica, collected in San Leandro Creek were the highest found among all sites sampled in San Francisco Bay. DDT and total PCB maximum concentrations in mussel tissue in Oakland Harbor ranged from 0.05 to $0.22 \mathrm{ppm}$ and from 0.18 to $0.88 \mathrm{ppm}$ dry weight, respectively. In comparison, DDT ranged from 0.01 to $0.04 \mathrm{ppm}$ and total PCB ranged from 0.03 to $0.08 \mathrm{ppm}$ in Tomales Bay mussels. 


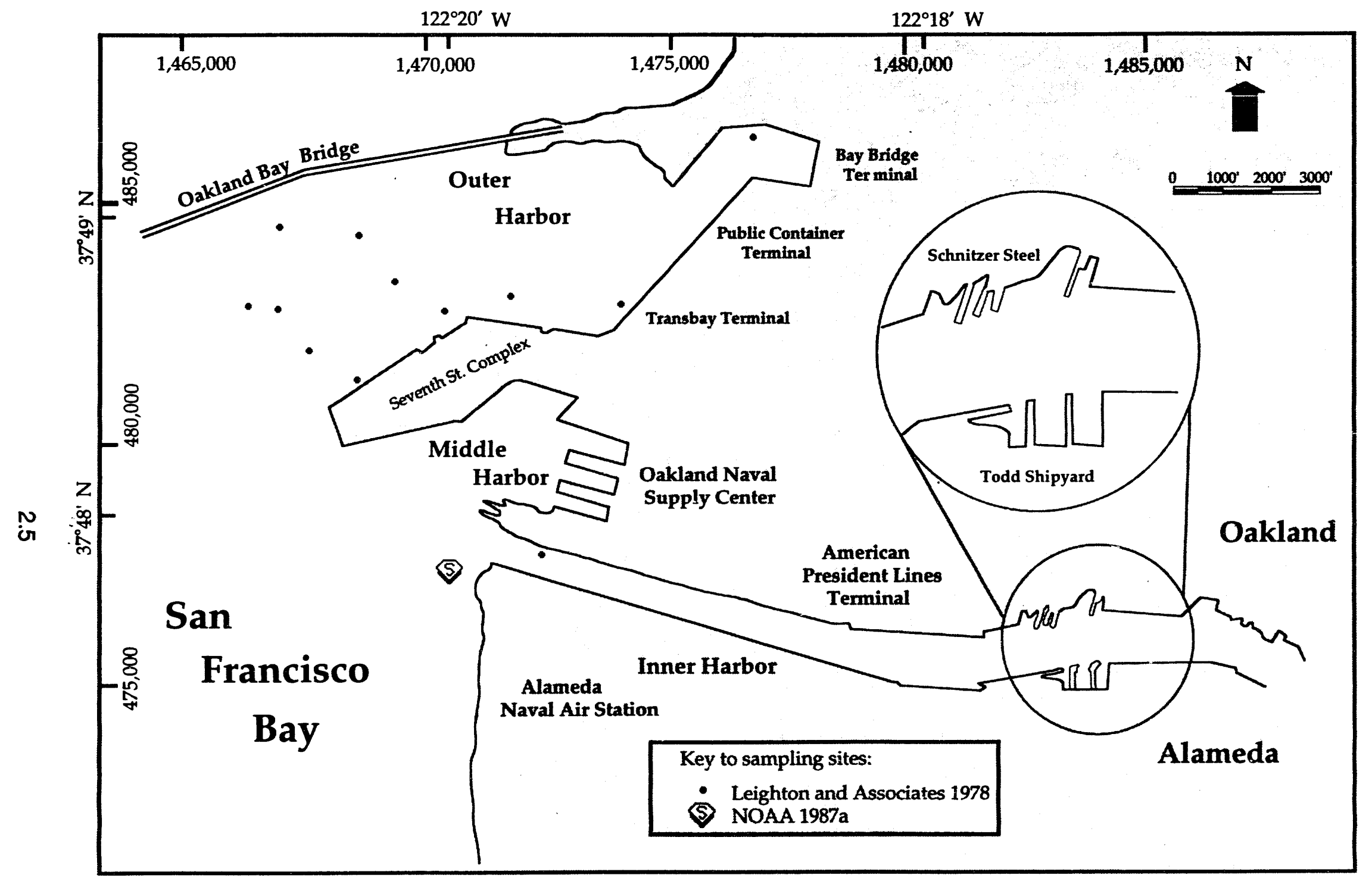

FIGURE 2.1. Locations in the Vicinity of Oakland Inner and Outer Harbors Where Infauna Samples Have Been Collected 


\subsection{OVERVIEW OF FISH DATA}

\subsubsection{Eish Distribution and Abundance}

Once the foremost fishing center on the West Coast, the San Francisco Bay-Delta Region has changed dramatically over the past century (Smith and Kato 1979). Much of the decline in fishery resources has been attributed to human-induced changes including heavy exploitation between 1870 and 1915, extensive land reclamation, water development projects, water pollution, and dredging. Although the full impact of these changes is unclear, the filling of shallow mud flats around the perimeter of the San Francisco Bay area has drastically reduced the amount of suitable habitat for oysters, clams, and bay shrimp. Many commercial fisheries that were once important to the Bay Area economy have disappeared, leading to the overall change in emphasis from commercial to recreational fishing. The only remaining commercial fisheries of note are those for Pacific herring, northern anchovy, and bay shrimp. The most important recreational fisheries of San Francisco Bay are those for chinook salmon, striped bass, sturgeon, shad, herring, anchovy, s. arry flounder, surfperch, and bay shrimp.

After reviewing the literature, Smith and Kato (1979) concluded that few quantitative data are available on the fishery resources of San Francisco Bay or on the life history of most of the animals that reside in San Francisco Bay, whether as seasonal migrants or residents. In particular, very limited information is available on the distribution and abundances of fish species within Oakland Inner and Outer Harbors. The few known locations within the harbors where fish have been sampled are shown in Figure 2.2. The reports summarized below suggest that many of the species that commonly occur in the San Francisco Bay estuary may also occur in Oakland Inner and Outer Harbors, but the reports do not indicate specific locations within these harbors where fish have been sampled.

According to the November 1984 feasibility study and environmental impact statement (USACE 1984), Oakland Inner Harbor is not considered a significant aquatic habitat for fish; however, its numerous commercial shoreline facilities do provide some shallow water habitat for small fish. USACE (1984) suggested that, although no fish studies have been conducted in Oakland Inner Harbor, the harbor may provide habitat for the following species: northern anchovy, northern midshipman, shiner perch, topsmelt, English sole, California tonguefish, Pacific herring, American shad, bay goby, pile perch, speckled sanddab, starry flounder, jacksmelt, bay ray, white croaker, brown smoothhound shark, Pacific staghorn sculpin, Pacific spiny dogfish, Pacific tomcod, and leopard shark. Public access and public facilities permit numerous sport fishing opportunities in the Inner Harbor. 


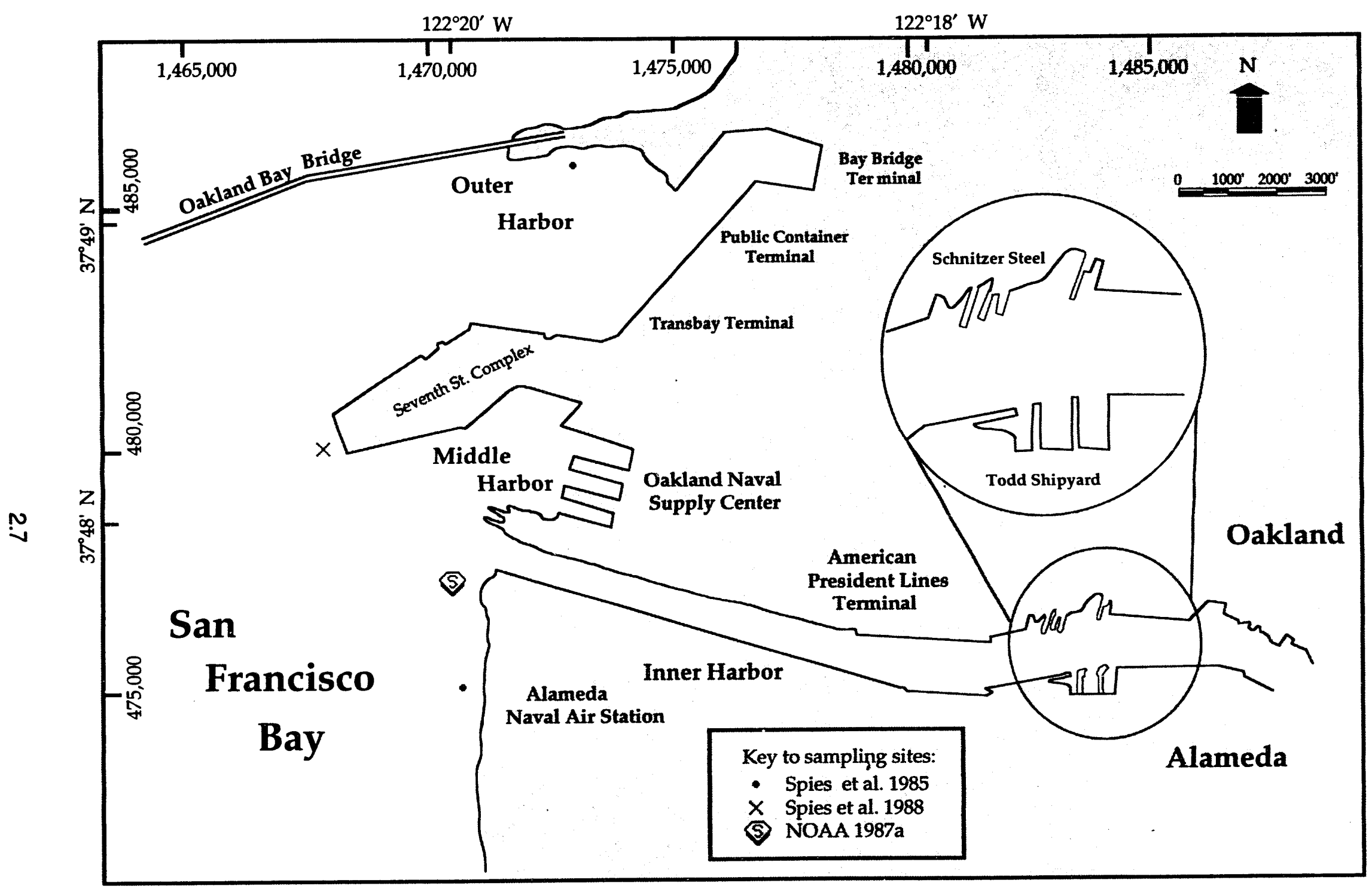

FIGURE 2.2. Locations in the Vicinity of Oakland Inner and Outer Harbors Where Fish Have Been Sampled 
In 1986, 11 species of fish, all of which are very common to the San Francisco Bay estuary (yellowfin goby, Pacific staghorn sculpin, English sole, plainfin midshipman, speckled sanddab, brown smoothhound shark, shiner surfperch, walleye surfperch, brown rockfish, white croaker, and northern anchovy), were collected in otter trawl samples within Oakland Outer Harbor (USACE 1986). The Outer Harbor apparently supports breeding populations of yellowfin goby and white croaker, because post-larvae, juveniles, and adults were collected in otter trawl samples. It is unknown whether or not the collected fish species are pollutionsensitive. Following completion of the original environmental impact statement in 1986, it was discovered that Pacific herring may utilize the Port of Oakland Outer Harbor intertidal and subtidal areas as a spawning ground in winter and early spring (USACE 1990b).

Booth et al. (1989) found that several species of fish may use Oakland Inner and Outer Harbors either temporarily or permanently. Among the fish species identified by the authors, the following support important sport and/or commercial fisheries: striped bass, chinook salmon, steelhead, American shad, white sturgeon, English sole, Pacific herring, northern anchovy, jacksmelt, California halibut, starry flounder, brown rockfish, and shiner surfperch.

Based on the level of sampling and analysis conducted to date, the potential exists for sediment contamination to significantly impact fish populations in Oakland Harbor. The following section on fish histopathology addresses potential fishery impacts from exposure to contaminated sediment.

\subsubsection{Eish Histopathology}

As noted by Long et al. (1988), demersal (bottom-dwelling) fish that are in frequent physical contact with sediments and/or feed on benthic prey are thought to receive a relatively high exposure to chemicals that may be present in the sediment. Hence, demersal fish are thought to be integrators of contaminant exposures, and some species can serve as reasonable biological indicators of trends in exposure to contamination.

From 1982 to 1987, NOAA supported research performed by the Lawrence Livermore National Laboratory (LLL) on the effects of organic contaminants in San Francisco Bay on the reproductive system of starry flounder. The reports on this research are briefly summarized below. Potential fishery impacts from exposure to contaminated sediment are described; a more thorough summary appears in Long et al. (1988).

Spies et al. (1985, 1988a, 1988b, and 1988c) provided compelling evidence that lipidsoluble organic contaminants had sublethal effects on the reproductive success of starry flounder. Laboratory-spawned females captured at various contaminated sites showed a highly significant negative relationship between hepatic mixed-function oxidase (MFO) activity and fertilization success. MFO activity in the liver is a measure of the enzymatic response of the fish to organic 
pollutant exposure, and is inducible by xenobiotic contaminants. San Francisco Bay sediments are extensively contaminated with xenobiotic compounds including PAHs, PCBs, phthalates, and benzthiazole-2 (r-mopholinyl), which can accumulate in fish tissues. The following results of the LLL studies are relevant to this Tier I evaluation of Oakland Harbor:

1. Chlorinated biphenyls had a direct toxic (sublethal) effect on both fertilization success and viable hatching of flounder eggs (Spies et al. 1985).

2. Some females living in contaminated conditions may experience complete reproductive inhibition (Spies et al. 1988a).

3. Concentrations of PCBs in spawned eggs were good predictors of embryological success (Spies et al. 1988a).

4. Immunoassays for P-450E could be incorporated into NOAA's NS\&T program as a sensitive and potentially inexpensive measure of the biochemical response of fishes to contaminants (Spies et al. 1988a).

5. Starry flounder collected in Oakland Outer Harbor had greater liver concentrations of PCBs and PAHs than those collected at a site in northern San Pablo Bay or the central portion of San Francisco Bay near Berkeley (Spies et al. 1988b).

6. Gamete viability, zygote formation, and embryological development decrease with increasing hepatic MFO activity of spawning females (Spies et al. 1988c).

7. Reproductive problems may be associated with only moderate environmental concentrations of chlorinated hydrocarbons. Thus, the xenobiotic compounds accumulated in San Francisco Bay had, and may continue to have, measurable effects on starry flounder reproductive and development processes (Spies et al. 1988c).

The authors concluded that their methods represent a promising approach for linking sublethal effects of organic contaminants to changes in coastal and estuarine fish populations. Because such contaminants are known to impact the reproductive and developmental success of flounder, the potential exists for deleterious population effects. The authors' methods could be applied to other coritaminated areas to measure the effects of urbanization on the health of demersal fish populations.

A major implication of these studies, relative to Oakland Harbor, is that more information on sediment contamination is needed to measure the potential impacts on the reproductive success of demersal fish populations. Few consistent statistical relationships between sediment chemistry and histopathological disorders have been demonstrated, largely because demersal fish are mobile and thus exposed to numerous, synergistic, and potentially aodverse stimuli. Histopaihological disorders may be the result of environmental factors other than bulk chemistry that have not yet been adequately researched. 


\subsection{IDENTIFICATION OF CONTAMINANTS OF CONCERN}

Quantitative data on sediment chemistry and biological testing specific to the Oakland Harbor navigation channel consist of evaluations of sediment for unrestricted, unconfined open-ocean disposal. The results of these studies, performed by and for USACE, are summarized below and include:

- Final Supplement I to the Environmental Impact Statement. Alameda County, California (USACE 1988)

- Confirmatory Sediment Analyses and Solid- and Suspended-Particulate-Phase Bioassays on Sediment from Oakland Inner Harbor. San Francisco, California (Word et al. 1988)

- Ecological Evaluation of Proposed Discharge of Dredged Material from Oakland Harbor into Ocean Waters (Phase I of -42-Foot Project [Word et al. 1990a])

- Ecological Evaluation of Proposed Discharge of Dredged Material from Oakland Harbor into Ocean Waters (Phase II of -42-Foot Project [Word et al. 1990b]).

Contaminants identified by these studies were scored according to criteria specified in the Green Book. These criteria, in addition to indicating the concentration of the contaminant in the dredged material and in the proposed disposal site, include toxicological importance, persistence in the environment, and propensity to bioaccumulate from sediments. The dredged material is considered toxicologically important if

1. the liquid phase contains concentrations that exceed applicable marine water quality criteria, after allowing for initial mixing of organohalogen compounds, mercury or mercury compounds, cadmium or cadmium compounds, oil of any kind or in any form, known carcinogens, mutagens or teratogens or materials suspected to be carcinogens, mutagens or teratogens by responsible scientific opinion; or

2. bioassay results of the suspended particulate phase or the solid phase indicate any occurrence of significant mortality due to dumping of the material.

Chemical compounds or forms that are not rapidly rendered nontoxic to marine life and non-bioaccumulative in the marine environment by chemical or biological degradation in the sea are considered persistent in the environment. The Green Book specifies that ocean dumping of "persistent inert synthetic or natural materials which may float or remain in suspension in the ocean in such a manner that they interfere materially with fishing, navigation, or other legitimate uses of the ocean" will not be approved by EPA or USACE under any circumstances.

Dredged material complies with the Green Book bioaccumulation criteria as long as bioaccumulation of contaminants of concern in organisms exposed to the dredged material does not exceed bioaccumulation in organisms exposed to the reference material. Material was judged to have a propensity to bioaccumulate if bioassay results from the suspended-particulate-phase or the solid-phase indicated the occurrence of significant bioaccumulation that resulted from 
dumping of organohalogen compounds, $\mathrm{Hg}$ or $\mathrm{Hg}$ compounds, $\mathrm{Cd}$ or $\mathrm{Cd}$ compounds, oil of any kind or in any form, known carcinogens, mutagens, or teratogens, or materials suspected to be carcinogens, mutagens, or teratogens by responsible scientific opinion. The Green Book covers the major chemical properties that control the propensity to bioaccumulate. These include hydrophobicity, aqueous solubility, stability, and stereochemistry.

Contaminant concentrations in Oakland Harbor sediments were compared to reference sediments from Alcatraz Disposal Site (USACE 1988, Power and Chapman 1988, McPherson et al. 1989), Point Reyes reference station PR-F and PR-C (Word et al. 1990a, 1990b), and Point Reyes reference station $37^{\circ} 51.00^{\prime} \mathrm{N} 123^{\circ} 01.50^{\prime} \mathrm{W}$ (Word et al. 1988). Based on these sediment chemistry evaluations, a list of contaminants of concern that have verified dry weight concentrations $\geq 1.2 \times$ reference sediment is presentod in Table 3.1 .

Confirmatory analyses of the presence, toxicity, and bioaccumulation of potential contaminants were conducted by USACE (1988) and Word et al. (1988, 1990a, 1990b). In December 1986, USACE (1988) collected sediment core samples from Oakland Inner Harbor, including three areas adjacent to Schnitzer Steel and four areas adjacent to Todd Shipyard and Oakland Outer Harbor (Figure 3.1). Bulk sediment analyses were conducted on all of the sediment samples. In addition, the samples from areas near Schnitzer Steel and Todd Shipyard were analyzed individually for 12 trace metals, 18 chlorinated pesticides, 7 PCB congeners, 16 PAHs, phenols, phthalates, cyanide, and sulfides. The results of these analyses are presented in Table 3.2.

Solid-phase bioassays were conducted by Power and Chapman (1988) using amphipods ( $R$. abronius), mysid shrimp ( $A$. sculpta), bent-nose clams ( $M$. nasuta), and polychaete worms ( $N$. caecoides). Of the three species tested, only the poiychaete worms had significantly lower survival in sediment from Oakland Inner or Outer Harbors, compared to survival in the reference sediment. Suspended-particulate-phase bioassays using mysid shrimp (A. sculpta), speckled sanddabs (C. stigmaeus), and mussel larvae ( $M$. edulis) showed that although the proposed dredged material was significantly more toxic to all the bioassay organisms than the Alcatraz Island reference sediment, in no case was the sediment from the tested portions of Oakland Inner and Outer Harbors toxic to $50 \%$ of the test organisms.

The bioaccumulation of contaminants was examined in the tissue of $M$. nasuta and $N$. caecoides (McPherson et al. 1989). The bioaccumulation results showed statistically higher concentrations of $\mathrm{Cr}, \mathrm{Pb}$, and $\mathrm{Zn}$ in the tissue of clams exposed to sediment from several areas within Oakland Inner Harbor than in the tissue of clams exposed to offshore reference sediment. The concentration of $\mathrm{Ag}$ in the tissue of polychaete worms was statistically higher in worms exposed to sediment from two areas within Oakland Inner Harbor than in worms exposed to reference sediments. 


\section{TABLE 3.1. Contaminants of Concern in Oakland Inner and Outer Harbors That Have Verified}

Dry Weight Concentrations $\geq 1.2 x$ Reference Sediments (See Footnotes A-C)

Contaminants of Concem

Outer Harbor

Oil and grease $\mathrm{TPH}$

Metals:

Ag

As

Cd

$\mathrm{Cr}$

$\mathrm{Cu}$

$\mathrm{Hg}$

$\mathrm{Ni}$

$\mathrm{Pb}$

Sb

Se

$\mathrm{Zn}$

Organics:

Butyltins

PCBs

PAHs

Pesticides

Word et al. 1990b(a); Power \& Chapman 1988(b); McPherson et al. 1989(b).

Word et al. 1990b; Power \& Chapman 1988.

Word et al. 1990b; McPherson et al. 1989.

Word et al. 1990b; USACE 1988(b); Power \& Chapman 1988; MCPherson et al. 1989. Word et al. 1990b; USACE 1988.

Word et al. 1990b; USACE 1988.

Word et al. 1990b; USACE 1988; Power \& Chapman 1988; McPherson et al. 1989. Word et al. 1990b; USACE 1988; Power \& Chapman 1988; McPherson et al. 1989. Word et al. 1990b; USACE 1988; Power \& Chapman 1988; McPherson et al. 1989. Word et al. 1990b; USACE 1988; Power \& Chapman 1988; MCPherson et al. 1989.

Power \& Chapman 1988; McPherson et al. 1989.

Word et al. 1990b; USACE 1988; Power \& Chapman 1988; McPherson et al. 1989.

Inner.Harbor

Oil and grease

Word et al. 19906

Word et al. 1990b; Power \& Chapman 1988; McPherson et al. 1989

Word et al. 1990b; McPherson et al. 1989.

Word et al. 1990b; Power \& Chapman 1988; McPherson et al. 1989.

TPH

Word et al. 1988(c), 1990a(a); McPherson et al. 1989.

Metals:

Ag

As

Cd

$\mathrm{Cr}$

$\mathrm{Cu}$

$\mathrm{Hg}$

$\mathrm{Ni}$

Po

So

Se

$\mathrm{Zn}$

Organics:

Butyltins

PCBs

PAHs

Pesticides

Word et al. 1988, 1990a.

USACE 1988; McPherson et al. 1989.

Word et al. 1988, 1990a; USACE 1988; MCPherson et al. 1989. Word et al. 1988, 1990a; USACE 1988; McPherson et al. 1989. Word et al. 1988, 1990a; USACE 1988.

Wond ot al. 1988, 1990a; USACE 1988; McPherson et al. 1989. Word et al. 1988, 1990a; USACE 1988; McPherson et al. 1989. Word et al. 1988, 1990a; USACE 1988; McPherson et al. 1989. Word et al. 1988, 1990a; USACE 1988; McPherson et al. 1989. Word et al. 1988, 1990a. Word et al. 1988, 1990a; McPherson et al 1989.

Word et al. 1988, 1990a; USACE 1988; McPherson et al. 1989.

Word et al. 1988, 1990a; USACE 1988.

Word et al. 1988, 1990a; USACE 1988; McPherson et al. 1989. Word et al. 1988, 1990a; USACE 1988; McPherson et al. 1989. Word et al. 1988, 1990a; USACE 1988; MCPherson et al. 1989.

(a) Point Reyes Reference Stations (PR-F, PR-C)

(b) Alcatraz Disposal Site

(c) Point Reyes Reference Station (37\%51.00' N, 12301.50'W) 


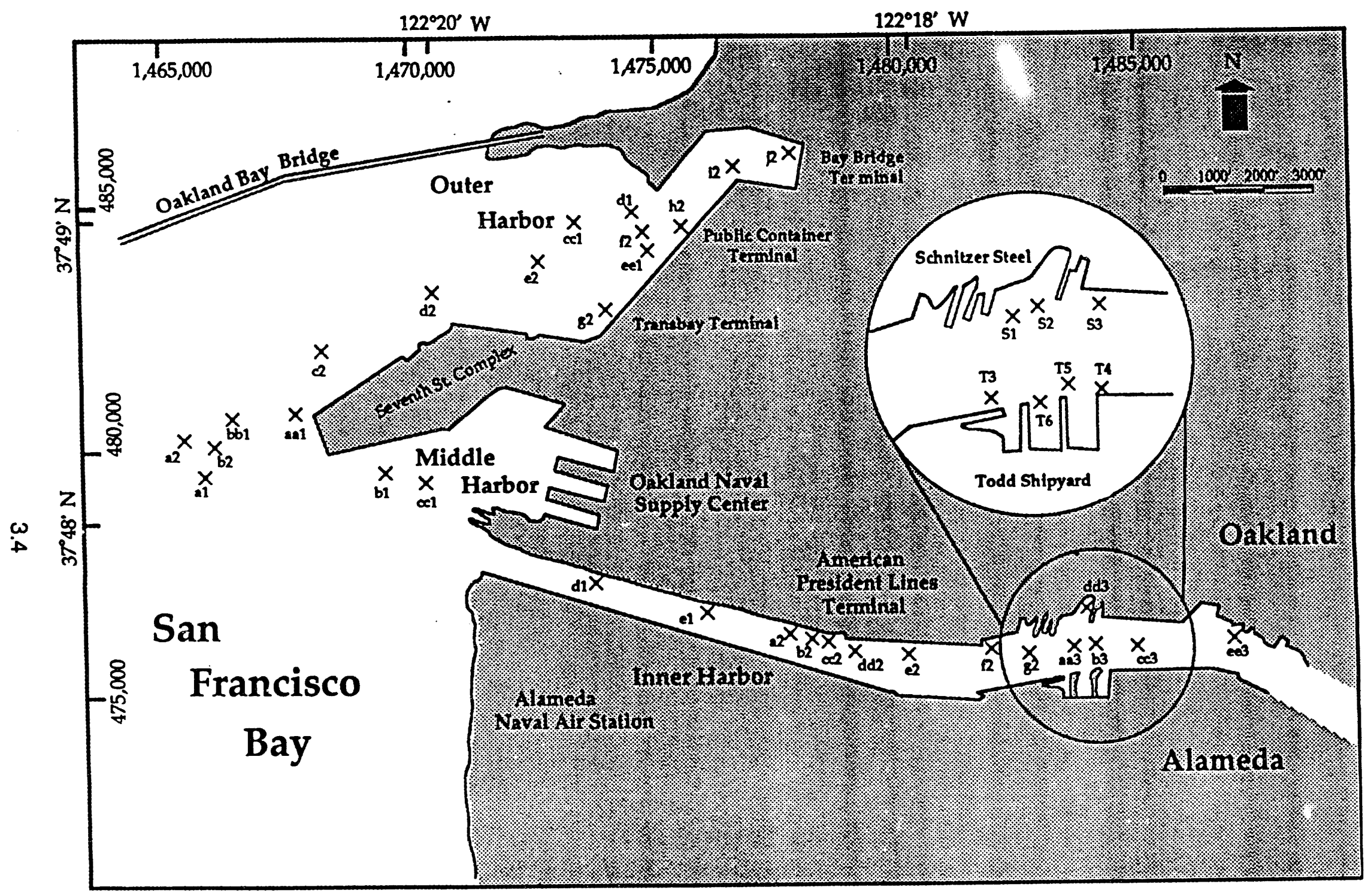

FIGURE 3.1. Locations in the Vicinity of Oakland Inner and Outer Harbors Where USACE (1988) Collected Samples for Sediment Chemistry Analyses and Bioassays 
TABLE 3.2. Summary of the Contaminants of Concern for Sediment Samples from Oakland Inner and Outer Harbors (USACE 1988)

\section{Sample \\ Site \\ Inner Harbor}

aa1

cc1

$\mathrm{cc} 2$

dd2

aa3

cc3

dd3

ee3

S1

S2

S3

$\mathrm{T} 4$

T5

T6

T7

\section{Quter Harbor}

bb1

cc1

ee1
As, Ni, Se

As, Se,

As, Ni, Se, $\mathrm{Zn}$

As, $\mathrm{Cu}, \mathrm{Ag}, \mathrm{Se}, \mathrm{Zn}$

$\mathrm{As}, \mathrm{Cr}, \mathrm{Cu}, \mathrm{Ni}, \mathrm{Ag}, \mathrm{Se}, \mathrm{Zn}$

As, $\mathrm{Cu}, \mathrm{Pb}, \mathrm{Hg}, \mathrm{Ni}, \mathrm{Ag}, \mathrm{Se}, \mathrm{Zn}$

As, $\mathrm{Cd}, \mathrm{Cr}, \mathrm{Cu}, \mathrm{Pb}, \mathrm{Hg}, \mathrm{Ni}, \mathrm{Se}, \mathrm{Zn}$

$\mathrm{As}, \mathrm{Cu}, \mathrm{Ni}, \mathrm{Ag}, \mathrm{Se}, \mathrm{Zn}$

$\mathrm{Cd}, \mathrm{Cu}, \mathrm{Pb}, \mathrm{Hg}, \mathrm{Ni}, \mathrm{Se}, \mathrm{Ag}, \mathrm{Zn}, \mathrm{PAHs}$

$\mathrm{Sb}, \mathrm{As}, \mathrm{Cd}, \mathrm{Cr}, \mathrm{Cu}, \mathrm{Pb}, \mathrm{Hg}, \mathrm{Ag}, \mathrm{Zn}, \mathrm{PAHs}, \mathrm{PCBs}$

$\mathrm{Sb}, \mathrm{Cd}, \mathrm{Cr}, \mathrm{Cu}, \mathrm{Pb}, \mathrm{Hg}, \mathrm{Ni}, \mathrm{Ag}, \mathrm{Zn}, \mathrm{PAHs}, \mathrm{PCBs}$

$\mathrm{Sb}, \mathrm{As}, \mathrm{Cr}, \mathrm{Cu}, \mathrm{Pb}, \mathrm{Hg}, \mathrm{Zn}, \mathrm{PAHs}, \mathrm{PCBs}$, tributyltin

$\mathrm{Sb}, \mathrm{As}, \mathrm{Cd}, \mathrm{Cr}, \mathrm{Cu}, \mathrm{Pb}, \mathrm{Hg}, \mathrm{Ni}, \mathrm{Ag}, \mathrm{Zn}, \mathrm{PAHs}, \mathrm{PCBs}$

$\mathrm{Sb}, \mathrm{As}, \mathrm{Cd}, \mathrm{Cr}, \mathrm{Cu}, \mathrm{Pb}, \mathrm{Hg}, \mathrm{Ni}, \mathrm{Ag}, \mathrm{Zn}, \mathrm{PAHs}, \mathrm{PCBs}$, tributyltin

$\mathrm{Sb}, \mathrm{As}, \mathrm{Cd}, \mathrm{Cr}, \mathrm{Cu}, \mathrm{Pb}, \mathrm{Hg}, \mathrm{Ni}, \mathrm{Ag}, \mathrm{Zn}, \mathrm{PAHs}, \mathrm{PCBs}$, tributyltin

As, $\mathrm{Cr}, \mathrm{Cu}, \mathrm{Hg}, \mathrm{Ni}, \mathrm{Se}, \mathrm{Zn}$

As, $\mathrm{Ni}, \mathrm{Se}$

As, $\mathrm{Cr}, \mathrm{Cu}, \mathrm{Hg}, \mathrm{Ni}, \mathrm{Se}, \mathrm{Zn}$

(a) The contaminants listed have verified concentrations above reference sediments from Alcatraz Disposal site. 
To help provide the scientific basis for determining whether Oakland Inner Harbor sediments were suitable for offshore disposal, MSL conducted an ecological evaluation of sediments that were collected to project depths of $-38 \mathrm{ft}$ MLLW (Word et al. 1988). The results of this study supplemented related preliminary studies conducted by USACE (1988). Additional toxicological and chemical evaluations of sediment from Oakland Inner and Outer Harbor, collected to the $-42-\mathrm{ft}$ project depth plus $2 \mathrm{ft}$ of overdepth, were performed by MSL in two phases. Phase I evaluated sediments from 20 stations in Oakland Inner Harbor (Word et al. 1990a). Phase II of the Oakland Harbor Studies evaluated sediments from six composites in Oakland Inner Harbor and 15 stations in Oakland Outer Harbor (Word et al. 1990b). The six composited stations in Oakland Inner Harbor and one station in Oakland Outer Harbor were added to Phase II after it was discovered that coring equipment could not penetrate to the -44-ft project depth at these stations during Phase I. The locations of all sites within Oakland Inner and Outer Harbors where Word et al. (1988, 1990a, 1990b) collected samples for sediment chemistry analyses and bioassays are shown in Figure 3.2 .

The dredged material collected by Word et al. (1988) was chemically analyzed and subjected to bioassay experiments, including solid-phase bioassays on four species of organisms ( $M$. nasuta, N. caecoides, Grandidierella japonica, and $R$. abronius) and suspendedphase bioassays using three species of organisms (A. sculpta, $C$. stigmaeus, and Crassostrea gigas). Word et al. (1990a, 1990b) conducted a series of solid-phase toxicity tests with four sensitive marine invertebrates ( $M$. nasuta, $N$. caecoides, Ampelisca abdita, and $R$. abronius), and assessed the bioaccumulation potential of sediment-associated contaminants in tissue of M. nasuta. The results of these analyses were used to develop the information presented in Tables 3.3 through 3.5. The cores from some sites were separated into two parts: 1) the upper core (-39 ft MLLW) designated by " $U$ " following the site number, and 2 ) the lower part of the same core ( $-42 \mathrm{ft} M L L W)$ designated by "L" following the site number.

Table 3.3 shows that in all of the Oakland Inner Harbor sites sampled for confirmatory sediment analyses, organotins were significantly accumulated in tissues of $M$. nasuta in comparison to reference sediments. Six of the sites (3-1, 3-2, SN-2L, SN-3L, TD-2U, TD-2L) also showed statistically significant mortality of test organisms in toxicity tests and $\geq 10 \%$ more mortality than in reference sediments. Table 3.4 shows that all of the Oakland Inner Harbor sites sampled for Phase I of the $-42 \mathrm{H}$ MLLW project depth (Word et al. 1990a) had statistically significant bioaccumulation, with the exception of Site $C H-5$. Six of the sites (SS-1-L, SS-2-L, SS-3-L, TS-4-U, TS-5-L, MA-1-U) also showed statistically significant mortality of test organisms in toxicity tests and $\geq 10 \%$ more mortality than reference sediments. Table 3.5 shows that six of the sites sampled for Phase II of the -42-ft MLLW project depth (Word et al. 1990b) had statistically significant bioaccumulation: OO-CH-2 (PCBs), OI-TS-5A (PAHs, Tributyltin), OIMA-1L (PAHs), OI-MA-2 (PAHs), OO-W-3 and OOW-4 (pesticides). Twelve of the sites in 
$122^{\circ} 20^{\prime} \mathrm{W}$

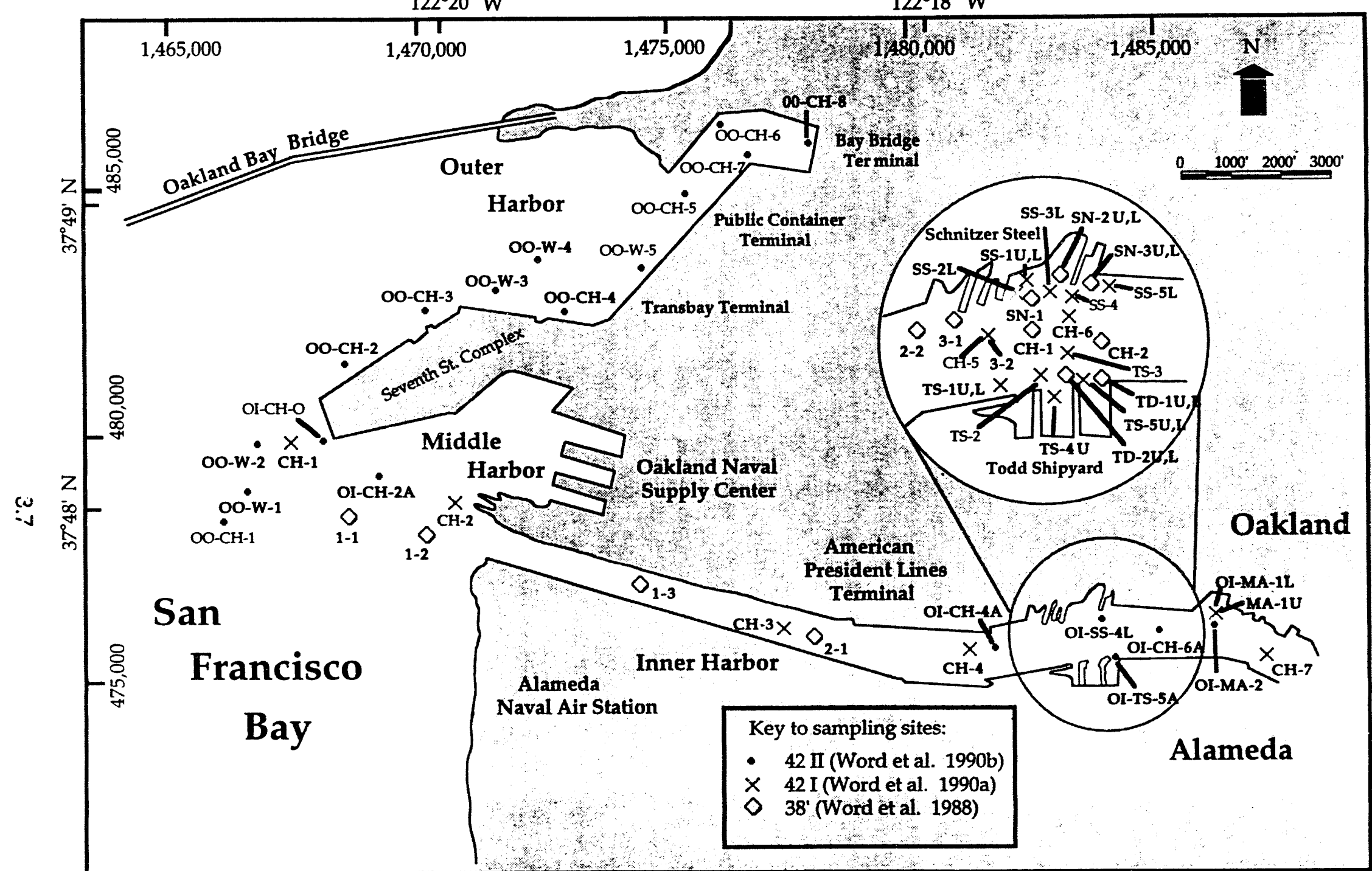

FIGURE 3.2. Locations Within Oakland Inner and Outer Harbors Where Word et al. $(1988,1990 \mathrm{a}, 1990 \mathrm{~b})$ Collected Samples for Sediment Chemistry Analyses and Bioassays 
TABLE 3.3. Summary of the Contaminants of Concern, Toxicological Importance, Persistence in the Environment, and Propensity to Bioaccumulate for Sediment Samples from Oakland Inner Harbor (Word et al. 1988). (Samples sites that showed significant toxicity, bioaccumulation, or both, are shown in Figure 3.3.)

\begin{tabular}{l}
$\begin{array}{c}\text { Sample } \\
\text { Site }\end{array}$ \\
\hline $1-1$ \\
$1-2$ \\
$1-3$ \\
$2-1$ \\
$2-2$ \\
$3-1$ \\
$3-2$ \\
CH-1 \\
CH-2 \\
SN-1 \\
SN-2U(c) \\
SN-2L(O) \\
SN-3U \\
SN-3L \\
TD-1U \\
TD-1L \\
TD-2U \\
$T D-2 L$
\end{tabular}

\section{Contaminants of Concem(a)}

oil \& grease, Sb,Cu,Pb.Hg,Ni,Se,Ag,Zn,As,Butyltins,PAHs,Pesticides $\mathrm{Sb}, \mathrm{Cu}, \mathrm{Pb}, \mathrm{Hg}, \mathrm{Ni}, \mathrm{Se}, \mathrm{Ag}, \mathrm{Zn}, \mathrm{As}, \mathrm{Bu}$ litins, PAHs

oil \& grease, TPH,Sb, Cu,Pb,Hg,Ni,Se,Ag.Zn,As,Butylins, PAHs

oil \& grease, TPH,Sb,Cr,Cu,Pb, Hg,Ni,Ag,Zn,As,Butylins,PAHs

oil \& grease, TPH,Sb,Cr,Cu,Pb,Hg,Ni,Se,Ag,Zn,As, Butyltins,PAHs

oil \& grease, TPH,Sb,Cr,Cu,Pb,Hg,Ni,Se,Ag,Zn,As, Butylins,PAHs

oil \& grease, $P$ PH, Sb,Cr,Cu,Pb,Hg,Ni,Se,Ag,Zn,As, Butylins, PAHs

oil \& grease, TPH,Sb,Cu,P, , Hg, Ni,Se,Ag, Zn,As, Buty! ins, PAHs

ol a grease, $\mathrm{Pb}, \mathrm{Cu}, \mathrm{Pb}, \mathrm{H}, \mathrm{Se}, \mathrm{Ag}, \mathrm{Zn}, \mathrm{As}, \mathrm{Bu}$,

Oi grease. TPH,

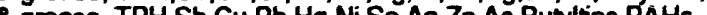

作,

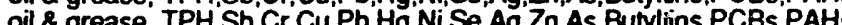

oil grease TPH Sb Co CrCuPb Hg NiSo Ag Zn As Butlins PCBs.PAHs

oil \& grease, Sb,Cr,Cu,Pb,Hg, Ni,Ag, Zn,As, Butylins, PCBs, PAHs

TD-2L

$\begin{array}{cc}\begin{array}{c}\text { Toxicological } \\ \text { Importance }\end{array} & \begin{array}{c}\text { Persistence } \\ \text { In Environment }\end{array} \\ & \begin{array}{c}\text { persistent } \\ \text { persistent } \\ \text { persistent } \\ \text { persistent } \\ \text { persistent } \\ \text { persistent } \\ \text { persistent } \\ \text { persistent } \\ \text { persistent } \\ \text { persistent }\end{array} \\ T & \begin{array}{c}\text { persistent } \\ \text { persistent } \\ \text { persistent } \\ \text { persistent } \\ \text { persistent } \\ \text { persistent }\end{array} \\ T & \text { persistent } \\ \text { persistent }\end{array}$

Propensity To Bioaccumulate

organotins

organotins

organotins

organotins

organotins
organotins

organotins

organotins

organotins

organotins

organotins

organotins

organotins, $\mathrm{Cr}$

organotins

organotins

organotins

organotins, $\mathrm{Pb}$ (a) The contarninants listed have verified concentrations above reference sediments.

(b) Bioassay results indicate significant toxicity ( $\geq 10 \%$ more mortality than in reference sediments).

(c) Lower core half (42-tit). 
TABLE 3.4. Summary of the Contaminants of Concern, Toxicological Importance, Persistence in the Environment, and Propensity to Bioaccumulate for Sediment Samples from Oakland Inner Harbor (Word et al. 1990a). (Samples sites that showed significant toxicity, bioaccumulation, or both, are shown in Figure 3.3.)

\begin{tabular}{l} 
Sample \\
Site \\
\hline CH-1 \\
CH-3 \\
CH-4 \\
CH-5 \\
CH-6 \\
CH-7 \\
SS-1-L(o) \\
SS-1-U(d) \\
SS-2-L \\
SS- -L \\
SS-5-L \\
TS-1-L
\end{tabular}

Contaminants of Concem(a)

Toxicological

Importance

$\mathrm{Cr}, \mathrm{Cu}, \mathrm{Hg}, \mathrm{Pb}$

gil \& grease, TPH, Ag, $\mathrm{Cr}$. Cu, $\mathrm{Hg}, \mathrm{Ni}, \mathrm{Pb}, \mathrm{Se}, \mathrm{T}, \mathrm{Zn}$, Butyltins, PCBs, PAHs

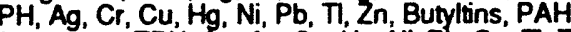

oll \& grease, TPH, Ag, As, Cu, Hg, Ni, Pb, Se, J, Zn, Butytins, PCBs, PAHs, DDE

, Ag. As, Cr. Cu, Hg. Ni, Pb, T1, Zn, Butyltins, PCBs, PAHs, DDE

cil \& grease, TPH, Ag. As, $\mathrm{Cr}, \mathrm{Cu}, \mathrm{Hg}, \mathrm{Ni}, \mathrm{Pb}$, Se, T, Zn, Zn, Butyltins, PCBs, PAHs

al \& grease, TPH, Ag, As, Cu, Hg, Ni, Pb, Se, n, Zn, Butyltins, PCBs, PAHs, DDE

gil \& grease, TPH, Ag, As, $\mathrm{Cu}$. $\mathrm{Hg}, \mathrm{Ni}, \mathrm{Pb}$, Se, $\mathrm{n}, \mathrm{Zn}$, Butyltins, PCBs, PAHs, DDE

cil \& grease, TPH, Ag, As, $\mathrm{Cu}, \mathrm{Hg}, \mathrm{Ni}, \mathrm{Pb}, \mathrm{Se}, \mathrm{T}, \mathrm{Zn}$, Butytins, PCBs, PAHs, DDE

oil \& grease, TPH, Ag, As, $\mathrm{Cu}$. $\mathrm{Hg}, \mathrm{Ni}, \mathrm{Pb}, \mathrm{Se}, \mathrm{M}, \mathrm{Zn}$, Butyltins, PCBs, PAHs, DDE
cil \& grease, TPH, Ag, As, Cr, Cu, Hg, Ni, Pb, Se, $\mathrm{Zn}$, Butytins, PCBs, PAHs

TS- $-4-U$

oil \& grease. TPH, Ag, As, Cr. Cu, Hg. Ni, Pb, Se, Th, Zn, Butylins, PCBs, PAHs, DDE oil \& grease, TPH, Ag, As, Cr. Cu, $\mathrm{Hg}, \mathrm{Ni}$. Pb. Se, $\mathrm{T}, \mathrm{Zn}$, Butyllins, PCBs, PAHs, DDE

TS-5-U

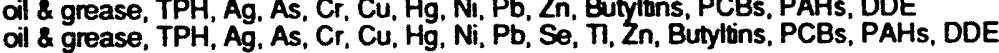

(a) The contaminants listed have verified concentrations up to 10x relerence sediments.

(b) $L=$ Lower core half $(42-t t)$

(c) $=$ Bioassay results indicate significant boxicity ( $\geq 10 \%$ more mortality than in reference sediments)

(d) $U=$ Upper core half $(38-\mathrm{tt})$

Persistence

In Environment

persistent

persistent

persistent

persistent

persistent

persistent

persistent

persistent

persistent

persistent

persistent

persistent

persistent

persistent

persistent

persistent
Propensity

Dr

Cr

Pb. PAHs, PCBs, DDE

Po. PAHs, PCBs, DDE

PAHs, PCBs, DDE

Pb, PAHs, PCBs, DDE

PAHs, PCBs, DDE

PAHs, PCBs. DDE

PAHs. PCBs, DDE

Cu, PAHs, PCBs.

vibutyltin. DDE

unbutylin

AHs, PCBs, tributylin

Cr. PAHs, PCBs, timbutylin PAHs, PCBs, DDE

tributyitin 
TABLE 3.5. Summary of the Contaminants of Concern, Toxicological Importance, Persistence in the Environment, and Propensity to Bioaccumulate for Sediment Samples from Oakland Inner and Outer Harbor (Word et al. 1990b). (Sample sites that showed significant toxicity, bioaccumulation, or both, are shown in Figure 3.3.)

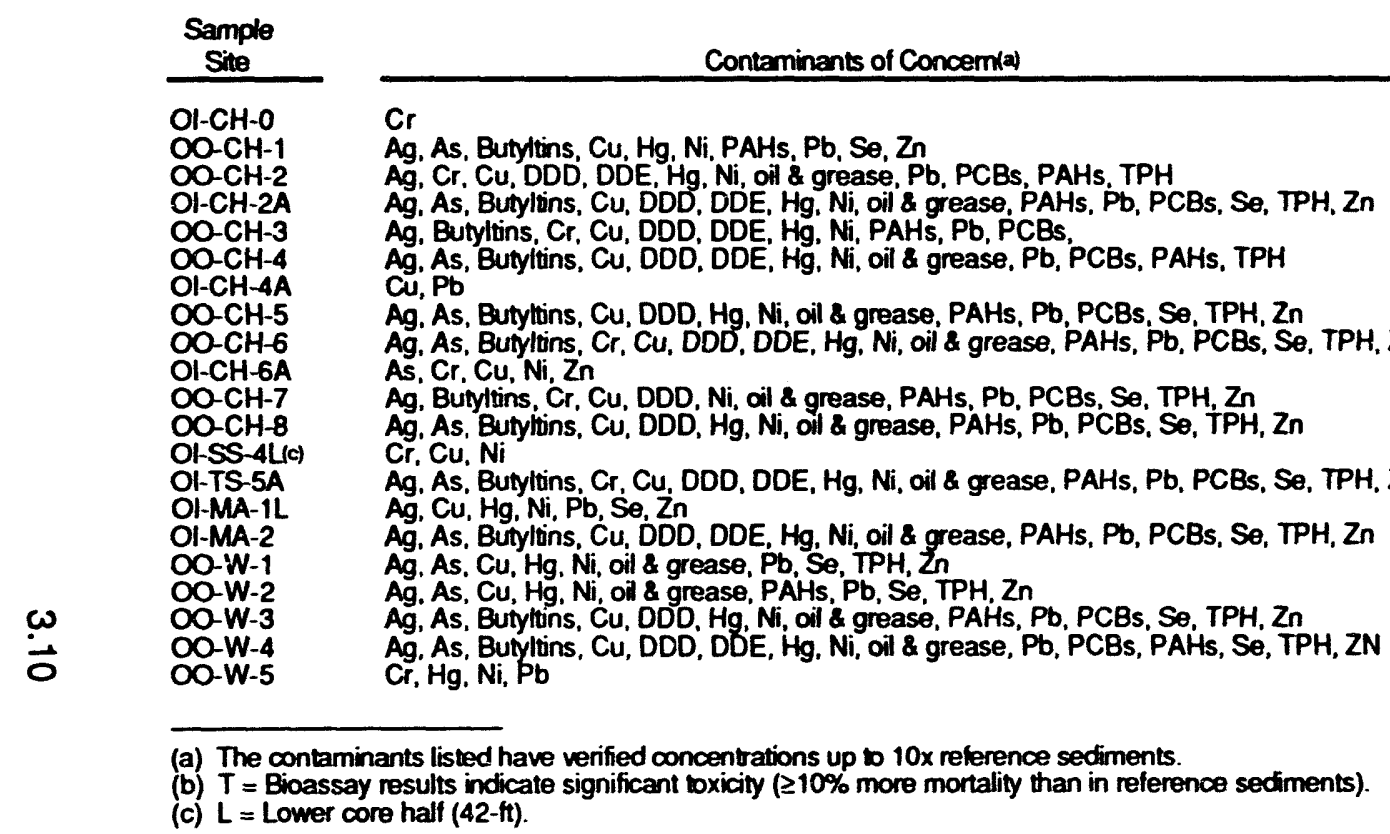

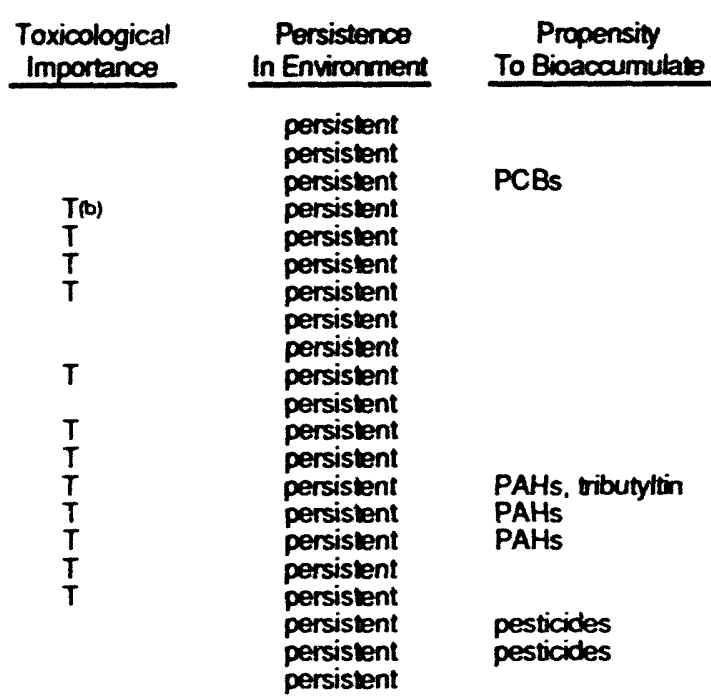

erence sediments). 
Table 3.5 (OI-CH-2A, OO-CH-3, OO-CH-4, O1-CH-4A, Ol-CH-6A, OO-CH-8, Ol-SS-4L, OI-TS-5A, OI-MA-1L, OI-MA-2, OO-W-1, OO-W-2) showed statistically significant mortality of test organisms in toxicity tests and $\geq 10 \%$ more mortality than in reference sediments.

The locations of all sites within Oakland Inner and Outer Harbors that showed statistically significant mortality to test organisms and $\geq 10 \%$ more mortality than in reference sediments, statistically significant bioaccumulation, or both, are presented in Figure 3.3. All the sites in Oakland Inner Harbor showed concentrations of persistent contaminants. Statistically significant mortality of test organisms in toxicity tests, or statistically significant bioaccumulation was observed at 16 sites. One particularly contaminated area was in the vicinity of Schnitzer Steel and Todd Shipyard. Eleven sites in this area showed both statistically significant toxicity and bioaccumulation. Although six composites in Oakland Outer Harbor showed either toxicity or bioaccumulation, no overall pattern of contamination was discernible. 


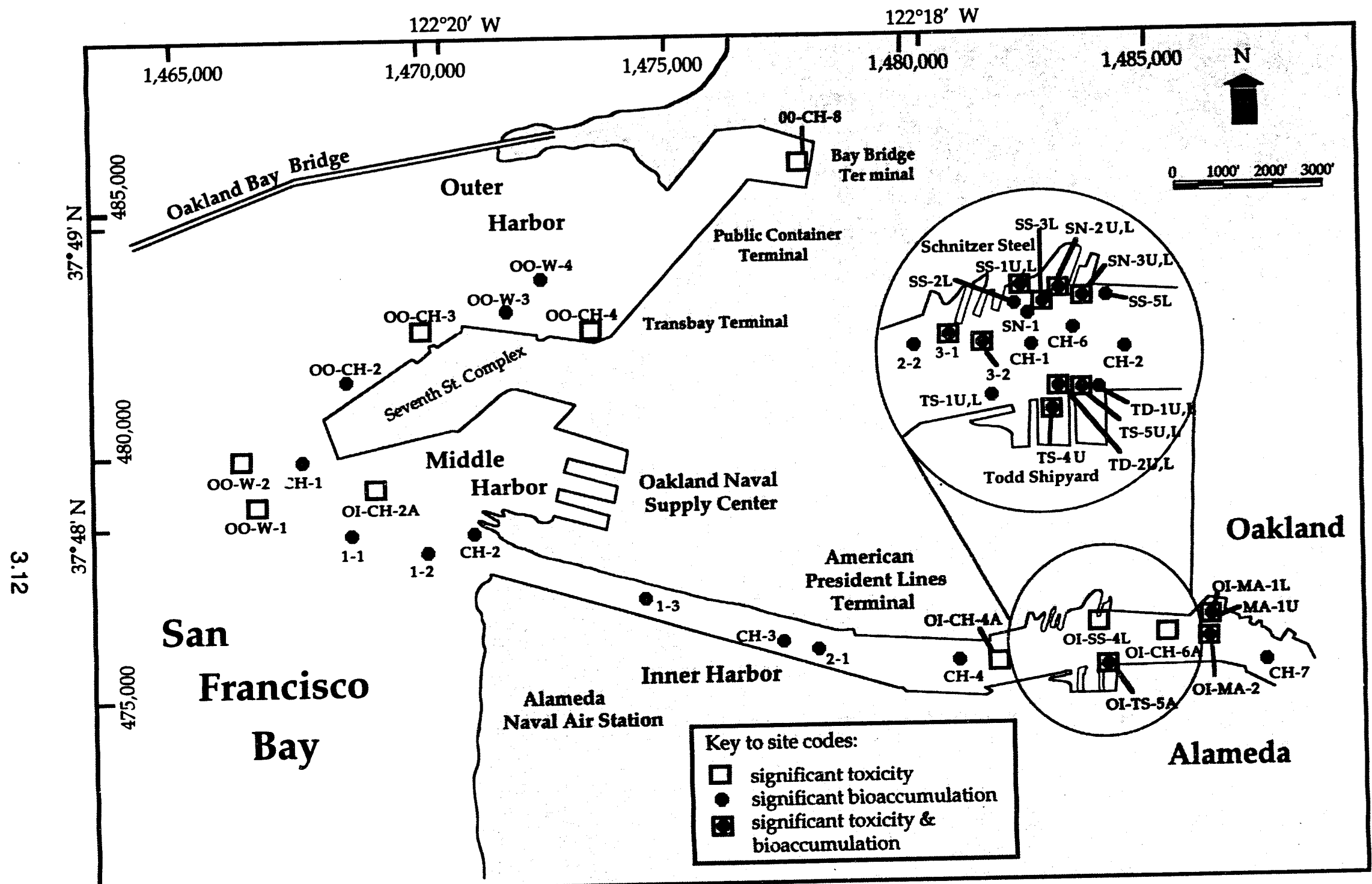

FIGURE 3.3. Locations Within Oakland Inner and Outer Harbors Sampled by Word et al. (1988, 1990a, 1990b) That Showed Significant Toxicity ( $\geq 10 \%$ More Mortality to Test Organisms Than in Reference Sediments), Significant Bioaccumulation, or Both 


\subsection{VERIFICATION OF TIER III SITE SELECTION}

Existing physical, chemical, and biological data on sediments proposed for dredging from Oakland Harbor have been compiled in Section 2.0 of this report. Section 3.0 identified contaminants that, because of their concentration and/or toxicological importance, have the greatest potential to adversely impact sensitive marine life. The purpose of this section is to verify that the Tier III sites sampled by Ward et al. (1992) and Kohn et al. (1992) were appropriately located to determine whether the potential exists for the dredged material from the project area to have an unacceptable impact.

Because sediments that would be removed during the Oakland Harbor Navigation Improvement Project failed to meet the exclusion criteria provided by federal rules (FR 227.13), it was necessary to perform further sampling and testing under Tier III evaluations. Sampling locations for the Tier III evaluations were initially selected by USACE-San Francisco District and subsequently modified through interagency discussions among representatives from EPA Region 9, the Regional Water Quality Control Board (RWQCB), USACE-San Francisco District, and the Waterways Experiment Station (WES). MSL was requested to plan and implement a sampling, testing, and analytical program that incorporated all recommendations for evaluation.

The MSL program was presented to representatives from USACE, Port of Oakland. RWQCB, and EPA at a coordination meeting in San Francisco on May $10-11,1990$ and to representatives from WES and EPA (Office of Research and Development) on May 16, 1990. A USACE "Memorandum For The Record" documents the results of the May 10 - 11, 1990 coordination meeting and scheduling of the WES meeting (Appendix A).

MSL used three characteristics to plan the additional Tier III sampling locations. These included the proximity to known historical or existing sources of contamination, the volume of material that would be dredged from a particular region within the harbor, and the presence of known contamination or biological effects associated with the sediment in that area. The stations selected for Tier III sampling are shown in Table 4.1, and the station locations are shown in Figure 4.1. The MSL sampling plan identified 53 stations within or near the existing and new federal navigation channels, turning basins, or maneuvering areas of Inner and Outer Oakland Harbors that required sediment testing because data on persistence, bioavailability, and relative bioaccumulation were lacking. Sediment was also sampled in areas between areas of known contamination to allow for a better delineation of the extent of sediment contamination or patterns related to various contamination sources. This same sampling approach was incorporated into a companion sampling and analytical effort to evaluate the potential contamination effects that might be associated with shipping activities within the berthing areas of Inner and Outer Oakland Harbors. 
TABLE 4.1. Stations Designated for Tier III Sampling

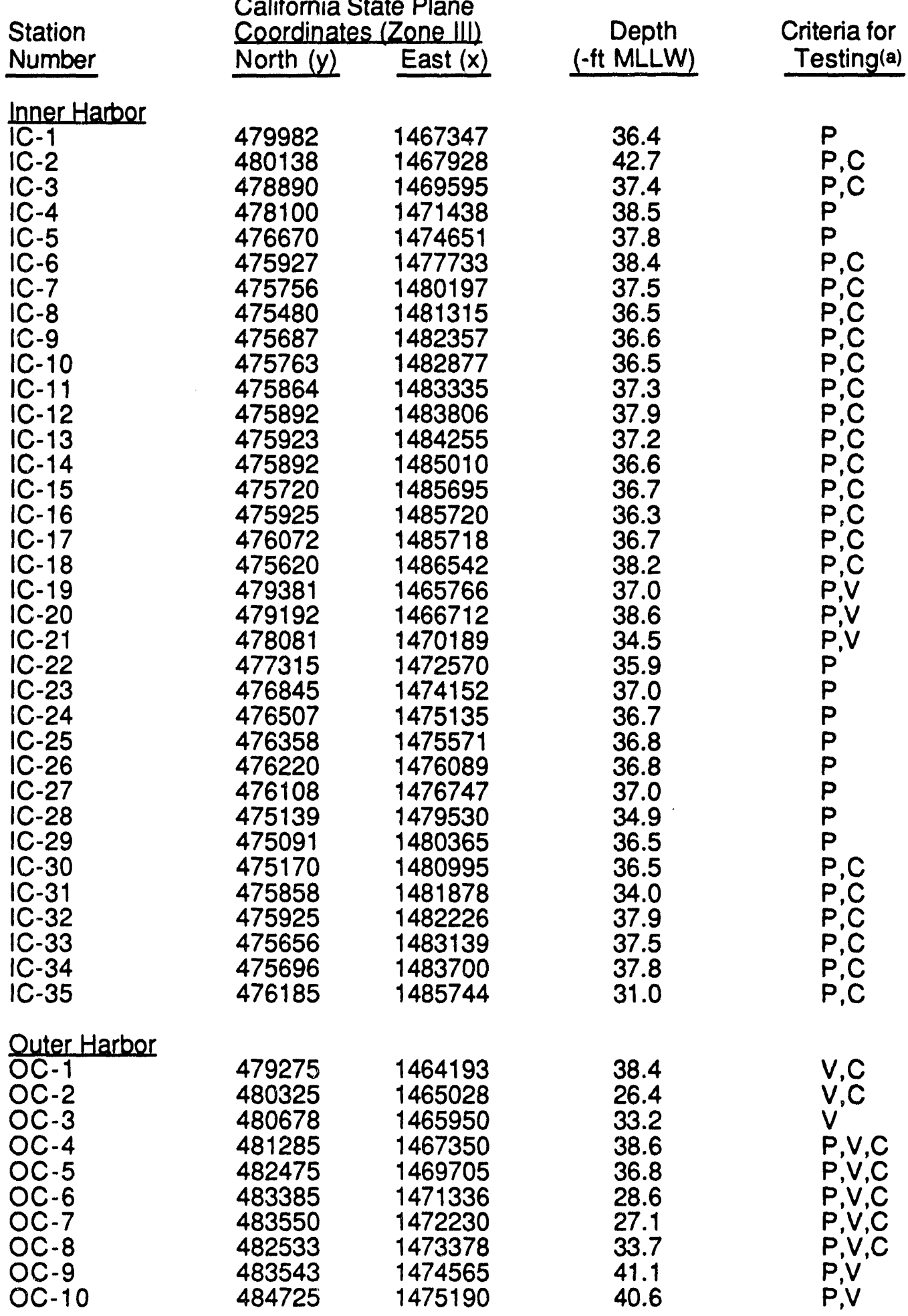


TABLE 4.1. (contd)

\begin{tabular}{|c|c|c|c|c|}
\hline $\begin{array}{l}\text { Station } \\
\text { Number }\end{array}$ & \multicolumn{2}{|c|}{$\begin{array}{l}\text { Califomia State Plane } \\
\text { Coordinates (Zone III) }\end{array}$} & $\begin{array}{c}\text { Depth } \\
\text { (-tt. MLLW) }\end{array}$ & $\begin{array}{l}\text { Criteria for } \\
\text { Testing }\end{array}$ \\
\hline \multicolumn{5}{|c|}{ Quter Harbor (contd) } \\
\hline $\begin{array}{l}\text { OC }-11 \\
O C-12 \\
O C-13\end{array}$ & $\begin{array}{l}486135 \\
485730 \\
485745\end{array}$ & $\begin{array}{l}1475970 \\
1476500 \\
1477685\end{array}$ & $\begin{array}{l}37.7 \\
41.0 \\
36.1\end{array}$ & $\begin{array}{l}\text { P.V } \\
P, V \\
P, V\end{array}$ \\
\hline$\frac{\text { Schnitzer Steel }}{\text { IS-1 }}$ & 476175 & 1482757 & 31.6 & $P, C$ \\
\hline $\begin{array}{l}\text { Todd Shipyard } \\
\text { IT-1 } \\
\text { IT-3 } \\
\text { IT-5 } \\
\text { IT-6 }\end{array}$ & $\begin{array}{l}475309 \\
475467 \\
475472 \\
475360\end{array}$ & $\begin{array}{l}1482752 \\
1483268 \\
1483525 \\
1483656\end{array}$ & $\begin{array}{l}37.5 \\
30.8 \\
34.2 \\
26.8\end{array}$ & $\begin{array}{l}P, C \\
P, C \\
P, C \\
P, C\end{array}$ \\
\hline
\end{tabular}

(a) $P$ = Proximity $; C=$ Known Contamination; $V=$ Volume 


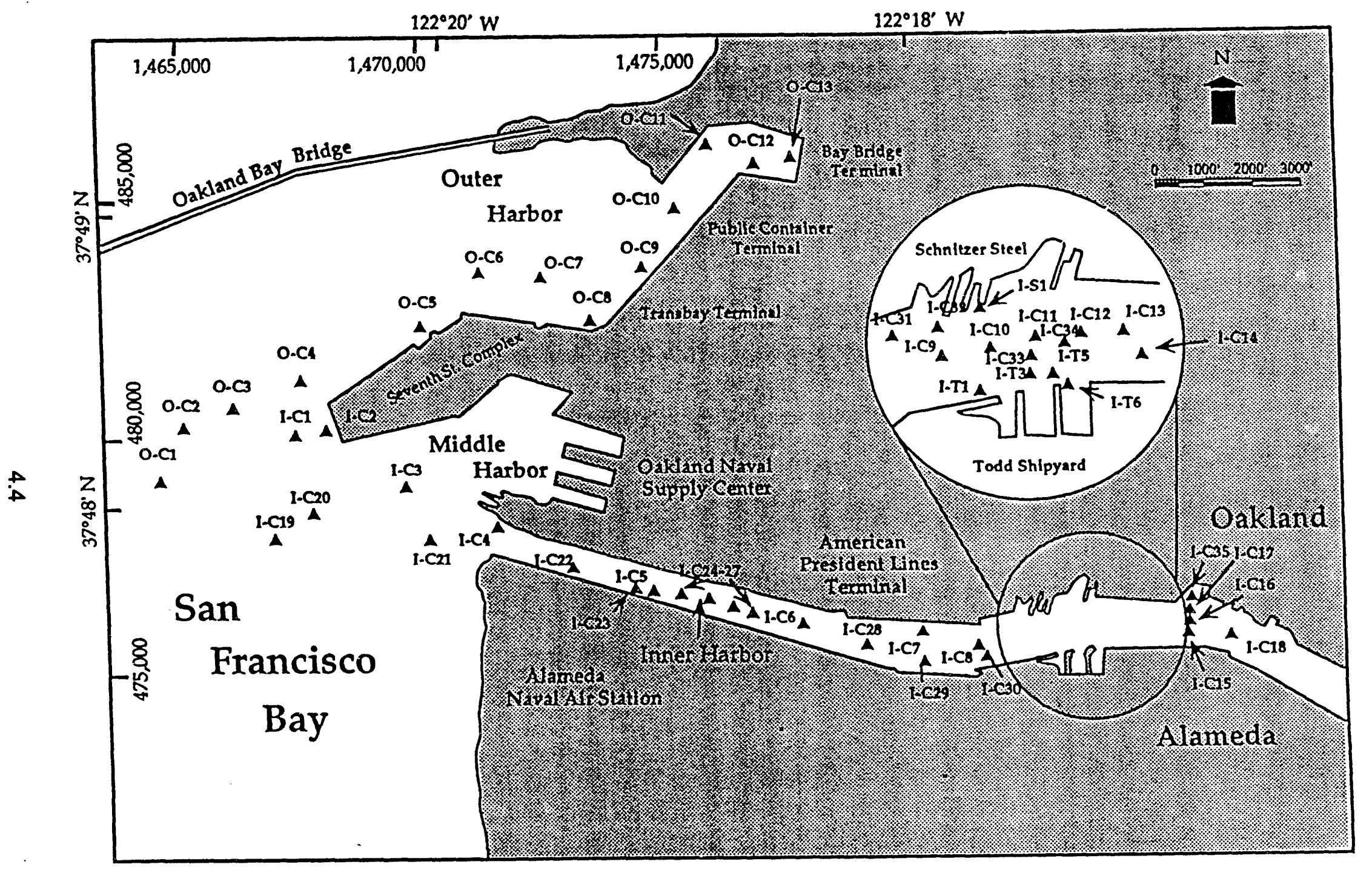

FIGURE 4.1. Sampling Stations for Tier III Testing 
In addition to evaluating the concentrations of the contaminants of concern at these sites, the toxicity of the solid and/or suspended phases of the sediment to six sensitive marine species and the availability and bioaccumulation of contaminants into tissues of two species of invertebrates were tested. In accordance with the sediment testing program (Appendix A), the organisms used for solid and/or suspended phase testing were the bent-riose clam (Macoma nasuta), burrowing polychaete (Nephtys caecoides), marine amphipod (Rhepoxynius abronius), speckled sanddab larvae (Citharichthys stigmaeus), mysid shrimp (Holmesimysis sculpta), and oyster larvae (Crassostrea gigas). M. nasuta and $N$. Caecoides were used to evaluate bioaccumulation potential of test, reference, and control sediments.

Tissue samples were analyzed for selected metals, high and low molecular weight PAHs, PCBs, chlorinated pesticides, and butyltins. Table 4.2 lists the parameters for which the Oakland Tier III tissue samples were analyzed. The results of this Tier III sediment testing, which are reported in Ward et al. (1992) and Kohn et al. (1992), suggest that the Tier III sites appear to have been appropriately located to determine that the dredged material from the project area may pose an unacceptable risk to sensitive marine organisms. The data from this Tier III sampling effort can now be compared to data from six different potential disposal sites, three within San Francisco Bay and three in the open ocean. This multiple comparison strategy provide USACE with an expedient and cost-effective method for concurrently evaluating alternative disposal sites, one of which may be designated as an open ocean (103) project-specific site, a regional (102) site, or an in-bay (404) disposal site. 
TABLE 4.2. Analytical Chemistry Requirements for Oakland Harbor Tissue Samples

\begin{tabular}{|c|c|c|c|c|}
\hline Parameters & $\begin{array}{l}\text { Detection } \\
\text { Limits(a) } \\
\text { Sediment } \\
\text { (mg/kg dry wt) } \\
\end{array}$ & $\begin{array}{l}\text { Number of } \\
\text { Samples }\end{array}$ & $\begin{array}{l}\text { Surrogate } \\
\text { Recovery }(\%)\end{array}$ & $\begin{array}{c}\text { Relative } \\
\text { Precision }(\%)\end{array}$ \\
\hline \multicolumn{5}{|l|}{ Metals } \\
\hline $\begin{array}{l}\mathrm{Ag} \\
\mathrm{As} \\
\mathrm{Cd} \\
\mathrm{Cr} \\
\mathrm{Cu} \\
\mathrm{Hg} \\
\mathrm{Ni} \\
\mathrm{Pb} \\
\mathrm{Se} \\
\mathrm{Zn}\end{array}$ & $\begin{array}{l}1.0 \\
1.0 \\
0.1 \\
1.0 \\
1.0 \\
0.02 \\
1.0 \\
1.0 \\
0.1 \\
1.0\end{array}$ & $\begin{array}{l}28 \\
28 \\
28 \\
28 \\
28 \\
28 \\
28 \\
28 \\
28 \\
28\end{array}$ & $\begin{array}{c}-.(b) \\
75-120 \\
85-115 \\
85-11 \\
75-125 \\
\cdots \\
\cdots \\
75-115 \\
-.\end{array}$ & $\begin{array}{l}15 \\
15 \\
15 \\
15 \\
15 \\
15 \\
15 \\
15 \\
15 \\
15\end{array}$ \\
\hline
\end{tabular}

Organic

Compounds

$\begin{array}{lllll}\text { Butyltins } & 0.01 & 28 & 40-140 & 20 \\ \text { PCBs(c) } & 0.02 & 28 & 50-150 & 50 \\ \text { PAHs(d) } & 0.02 & 28 & 50-150 & 50 \\ \text { Pesticides }(\theta) & 0.002 & 28 & 50-150 & 50\end{array}$

(a) Target detection limits; all efforts were made to reach lowest practical detection limits.

(b) Not available.

(c) Reported as Aroclor equivalents 1242, 1248, 1254, and 1260 and total PCB, EPA Method 8080.

(d) All compounds on EPA Method 610 list. Analyzed using Method 8270 in S.I.M. mode.

(e) All compounds on EPA Method 608 list. Analyzed using Method 8080. 


\subsection{REFERENCES}

Bienert, R.W., D.K. Shreffler, J.Q. Word, and N.P. Kohn. 1992. Tier I Ecological Evaluation for Phase III Channel Improvements to the John F. Baldwin Ship Channel. Pacific Northwest Laboratory, Richland, Washington.

Booth, P. N., D. M. Johns, J. J. Greene, and J. R. Kane. 1989. Central San Francisco Bay Projects: Dredged Material Disposal Site Investigation. Prepared by PTI Environmental Services for the U.S. Arrny Corps of Engineers-San Francisco District under Contract DACW07-88-C0026. San Francisco, California.

Chapman, P. M., R. N. Dexter, S. F. Cross, and D. G. Mitchell. 1986. A Field Trial of the Sediment Quality Triad in San Francisco Bay. NOAA Technical Memorandum NOS OMA 25. Prepared by E.V.S. Consultants for the National Oceanic and Atmospheric Administration, Seattle, Washington.

Davis, J.A., A.J. Gunther, B.J. Richardson, J.M. O'Connor, R.B. Spies, E. Wyatt, E. Larson, and E.C. Meiorin. 1991. Status and Trends Report on Pollutants in the San Francisco Estuary. San Francisco Bay-Delta Aquatic Habitat Institute, Richmond, California.

Earth Metrics Inc. 1990. Historical Research of Land Use and Industry in the Federal Ship Channel Study Area Oakland, California. Prepared by Earth Metrics Inc. for the U.S. Army Corps of Engineers-San Francisco District, San Francisco, California.

EPAIUSACE. 1977. Ecological Evaluation of Proposed Discharge of Dredged Material into Ocean Waters. Implementation Manual for Section 103 of Public Law 92-532 (Marine Protection, Research, and Sanctuaries Act of 1972). Environmental Effects Laboratory, U.S. Army Engineer Waterways Experiment Station, Vicksburg, Mississippi.

EPAIUSACE. 1990. Evaluation of Dredged Material Proposed for Ocean Disposal (Testing Manual)-Draft. Environmental Protection Agency, Office of Marine and Estuarine Protection, Washington, D.C.

EPAUSACE. 1991. Evaluation of Dredged Material Proposed for Ocean Disposal (Testing Manual). EPA-503/8-91/001. Environmental Protection Agency, Office of Marine and Estuarine Protection, Washington, D.C.

Gunther, A.J., J.A. Davies, and D.J.H. Phillips. 1987. An Assessment of Loading of Toxic Contaminants to the San Francisco-Bay Delta. Aquatic Habitat Institute, Richmond, California.

Gunther, A.J., J.A. Davis, D.J.H. Phillips, K.S. Kramer, B.J. Richardson, and P.B. Williams. 1990. Status and Trends Report on Dredging and Watenway Modification in the San Francisco Estuary. San Francisco Bay-Delta Aquatic Habitat Institute, Richmond, California.

Hopkins, D.R. 1986. Atlas of the Distributions and Abundances of Common Benthic Species in San Francisco Bay, California. Water Resources Investigations Report 86-4003. U.S. Geological Survey, Washington, D.C.

Kohn, N.P., J.A. Ward, M.L. Mayhew, J.Q. Word, E.S. Barrows, S.M. Goodwin, and L.F. Lefkovitz. 1992. Ecological Evaluation of Proposed Discharge of Dredged Material from Oakland Harbor into Ocean Waters (Phase IIIB of -42-Foot Project). PNL-8174 Vol. 1. Pacific Northwest Laboratory, Richland, Washington.

Leighton and Associates. 1978. "Analysis of Benthic Infauna Samples, Oakland Outer Harbor, September 1975-March 1976." In U.S. Army Corps of Engineers, Dredge Disposal Study, San Francisco Bay and Estuary. Appendix N, Addendum, 109 p. Oakland, California.

Long, E., D. MacDonald, M. B. Matta, K. VanNess, M. Buchman, and H. Harris. 1988. Status and Trends in Concentrations of Contaminants and Measures of Biological Stress in San Francisco Bay. NOAA Technical Memorandum NOS OMA 41. National Oceanic and Atmospheric Administration, Seattle, Washington. 
Long, E.R. and R. Markel. 1992. An Evaluation of the Extent and Magnitude of Biological Effects Associated with Chemical Contaminants in San Francisco Bay, California. NOAA Technical Memorandum NOS ORCA 64. National Oceanic and Atmospheric Administration, Seattle, Washington.

McPherson, C. A., E. A. Power, and P. M. Chapman. 1989. Chemical Characterization and Bioassay Testing of Sediments from Oakland Harbor. E.V.S. Project No.2/274-09.4. Prepared by E.V.S. Consultants for the U.S. Army Corps of Engineers-San Francisco District, San Francisco, California.

NOAA. 1987. National Status and Trends Program: Progress Report and Preliminary Assessment of Findings of the Benthic Surveillance Project - 1984. Ocean Assessment Division, Rockville, Maryland.

Nichols, F. H. 1979. "Natural and Anthropogenic Influences on Benthic Community Structure in San Francisco Bay." In San Francisco Bay: the Urbanized Estuary. T. J. Conomos (ed). FiftyEighth Annual Meeting of the Pacific Division/American Association for the Advancement of Science, San Francisco, California.

Phillips, D.J.H. 1987. Toxic Contaminants in the San Francisco Bay-Delta and Their Possible Biological Effects. Aquatic Habitat Institute, Richmond, Califomia.

Power, E. A., and P. M. Chapman. 1988. Analysis and Bioassay Testing of Sediments Collected from Oakland Outer Harbor. E.V.S. Project No. 2/274-08.3. Prepared by E.V.S. Consultants for the U.S. Army Corps of Engineers-San Francisco District, San Francisco, California.

Shopay, N. T. and D. E. Bruggers. 1988. Sediment Evaluation Naval Supply Center Piers 4 and 5 Oakland, California. Prepared by Harding Lawson Associates, Oakland, California.

Schmitt, W. L. 1921. The Marine Decapod Crustacea of California. University of California Press, Berkeley; California.

Smith, S. E. and S. Kato. 1979. "The Fisheries of San Francisco Bay: Past, Present, and Future." In San Francisco Bay: the Urbanized Estuary. T. J. Conomos (ed.) Fifty-Eighth Annual Meeting of the Pacific Division/American Association for the Advancement of Science, San Francisco, California.

Spies, R. B., D. W. Rice Jr., P. A. Montagna, R. R. Ireland, J. S. Felton, S. K. Healy, and P. R. Lewis. 1985. Pollutant Body Burdens and Reproduction in Platichthys stellatus from San Francisco Bay. UCID-20386, Lawrence Livermore National Laboratory, Livermore, California.

Spies, R. B., D. W. Rice Jr., and M. Prieto. 1988a. The Response of the Reproductive System in Platichthys stellatus to Organic Contamination in San Francisco Bay. Lawrence Livermore National Laboratory, Livermore, California.

Spies, R. B., D. W. Rice Jr., and J. Felton. 1988b. "Effects of Organic Contaminants on Reproduction of the Starry Flounder Platichthys Stellatus in San Francisco Bay. I. Hepatic Contamination and Mixed-Function Oxidase (MFO) Activity During the Reproductive Season." Marine Biology 98:181-189.

Spies, R. B., and D. W. Rice Jr. 1988c. "Effects of Organic Contaminants on Reproduction of the Starry Flounder Platichthys Stellatus in San Francisco Bay. II. Reproductive Success of Fish Captured in San Francisco Bay and Spawned in the Laboratory." Marine Biology 98: 191-200.

USACE. 1990a. Long-Term Management Strategy for Dredged Material Disposal in the San Francisco Bay Region; Phase I: Evaluation of Existing Management Options. U.S. Army Corps of Engineers-San Francisco District, San Francisco, California.

USACE. 1990b. Draft Supplement to the Environmental Impact Report for the Redevelopment of Carnation Terminal Area. U.S. Army Corps of Engineers-San Francisco District, San Francisco, California. 
USACE. 1988. Oakland Harbor. Deep-draft Navigation Improvements Design Memorandum Number 1, General Design and Final Supplement i to the Environmental Impact Statement. U.S. Army Corps of Engineers-San Francisco District, San Francisco, California.

USACE. 1986. Draft Environmental Impact Report, Redevelopment of Carnation Terminal Area. U.S. Army Corps of Engineers-San Francisco District, San Francisco, California.

USACE. 1984. Feasibility Study, Environmental Impact Statement on Oakland Inner Harbor, California Deep-Draft Navigation. U.S. Army Corps of Engineers-San Francisco District, San Francisco, California.

USACE. 1979. Dredge Disposal Study for San Francisco Bay and Estuary, Appendix B pollutant distribution study. U.S. Army Corps of Engineers-San Francisco District, San Francisco, California.

Ward, J.A., J.Q. Word, M.R. Pinza, H.L. Mayhew, E.S. Barrows, and L.F. Lefkovitz. 1992. Ecological Evaluation of Proposed Discharge of Dredged Material from Oakland Harbor into Ocean Waters (Phase IIIA of -42 Foot Project). PNL-8302 Vol. 1, Pacific Northwest Laboratory, Richland, Washington

Word, J. Q. J. A. Ward, C. W. Apts, D. L. Woodruff, M. E. Barrows, V. I. Cullinan, J. L. Hyland, and J. F. Campbell. 1988. Confirmatory Sediment Analyses and Solid and Suspended Particulate Phase Bioassays on Sediment from Oakland Inner Harbor, San Francisco, Califormia. PNL-6794, Pacific Northwest Laboratory, Richland, Washington.

Word, J. Q., J. A. Ward, J. A. Strand, V. I. Cullinan, E. A. Crecelius, W. Steinhauer, and J. L. Hyland. 1990a. Ecological Evaluation of Proposed Discharge of Dredged Material From Oakland Harbor Into Ocean Waters (Phase I of -42 -Foot Project). PNL-7484, Pacific Northwest Laboratory, Richland, Washington.

Word, J. Q., J. A. Ward, J. A. Strand, N. P. Kohn, and A. L. Squires. 1990b. Ecological Evaluation of Proposed Discharge of Dredged Material from Oakland Harbor into Ocean Waters (Phase II of -42-Foot Project). PNL-7483, Pacific Northwest Laboratory, Richland, Washington. 


\section{APPENDIX}

MEMORANDUM FOR THE RECORD. 30 MAY 1990 
CESPN-PE-P (walls)

\section{MEMORANDUM FOR THE RECORD}

SUBJECI: Sediment Testing Program for the Oakland Harbor Navigation Improvement Project - Coordination Meetings of 10 - 11 May 1990.

\section{References:}

a. Draft Ecological Evaluation of Proposed Discharge of Dredged Material Into Ocean Waters ("Green Book"); U.S. Environmental Erotection Agency and Department of the Army, U.S. Army Corps of Engineers; January 1990.

b. Draft Ecological Evaluation of Proposed Discharge of Dredged or Fill Material into Waters of the United States ("Gold Book"); U.S. Enviranmental Protection Agency and Department of the Army, U.S. Army Corps of Engineers; in preparation.

c Draft Work Plan Ecological Evaluation of Proposed Discharge of Dredged Material from the Oakland Harbor, Phase III, Parts $A$ and $B$, Dr. J.Q. Word, Battelle Marine Sciences Laboratory, Sequim, WA, in preparation.

d. Confirmatony Sediment Analyses of solid and suspended Particulate phase Bioassays on Sediment From Oakland Inner Harbor...; J.Q. Word et al, Battelle Marine Sciences Laboratory, Sequin, WA, December 1988.

e Proposal to Determine the Potential Impacts of Disposal of Oakland Harbor Deepening Project Dredged Material in San Francisco Bay, V.A. McFarland, F.J. Reilly, and C.H. Lutz, Ecosystem Research and Simulation Division, Environmental Laboratory, USAE Waterways Experiment station, Vicksburg, MS, 11 April 1990.

f. Scope of Work for Evaluating the Chronic Sublethal Effects of San Francisco Bay Area Sediments, Dr. T. Dillon, Ecosystem Research and Simulation Division, Environmencal Laboratory, USAE Waterways Experiment station, vicksburg, MS, 11 May 1990.

2. Technical representatives of the San Francisco District, the USAE Waterways Experiment Station, EPA Region IX, the San Francisco Bay Regional Water Quality control Board, the Port of Oakland, and Battelle Marine Sciences Iaboratory (study contractor) met at the San Francisco District, May 10th and 11th 1990, to review and coordinate the sediment evaluation program for the Oakland Harbor Navigation Improvement Project. Attendees are itsted in attachment A. The meeting agenda is provided as attachment $B$.

3. The technical project manager for the Oakland Harbor deepening project provided an overview of project background, cost sharing responsibilities of the local sponsor and the federal government in regard to testing, and the project schedule and how it impels the testing program. Ensuing 
discussion centered on disadvantages of the schedule driving the testing program. Region IX expresed concern that the acuatic testing was likely to be the eirat major application of the new, draft "Green Book" and that time should be allotted for the Enviranmental Protection Agancy's office of Resarch and Development (ORD), specistcally Mr. N. Rubinstein at ORD, to review the proposed program. Another meting, with ORD participation, was suggested by the District to both facilitate ORD review and to reasonably minimize program delays.

4. The District and Battelle presented a sampling plan for project sediments to be evaluated for aquatic disposal. The sample locations identified were derived from analysis of data cbtained through testing of project sediments under the previous version of the "Green Book" during 1988 and 1989; from survey of annual maintenance dredging sediment evaluations; from review of historical land uses in the vicinity of the Inner and outer Harbors, from identification of NPDES discharges, storm drain outfalls, RCRA, CERCIIS, RWQCB, and other abandoned sites; and from audit of information on past hazardous spills in the vicinity of the project. Region IX maintained that the large quantity of data to review and their unfamiliarity with the sinal draft version of the "Green Book" probibited their expeditious comment on the sampling plan. The District pointed out that a complete sampling plan was not reguisite to initiating the first phase of the multiphase sampling program. Another meeting, tenatively schedured for August 1990, is planned to further coordinate the sampling. If after review of available information, Region IX or the RWQCB provides reasonable justification for additional samples sites or identifies additional areas of concern which have not been previously characterized, those sites may be included in either the August or November 1990 sampling episodes. All sample sites currently identifled for inclusion in the testing progran were located on project maps during the subject meeting. Copies of the maps are belng prepared for distribution.

5. Retesting of sediments in the north and south "wings" of the Inner Harbor turning basin, as configured in the 1988 GDM/SEIS, was not proposed. It was agreed that sufficient data existed to determine that the sediments above the Merritt Sands in the wings of the turning basin are unsuitable for uncestricted ocean disposal and that the Merritt sands in the lower parts of the turning basin wings are suitable for unrestricted ocean disposal. The representative of the RWQCB has indicated that without further testing, the sediments above the Merritt Sands in the turning basin should also be considered unsuitable for unrestricted disposal within San Francisco Bay. District personnel explained that segregation of the unsuitable and the suitable sediments could be easily acomplished in the dredging process. The upper contact of the Merritt Sands in the vicinity of the turning basin is cemented with a clay fraction and forms an extremely hard surface. The unsuitable layer above the Merritt Sands has a consistency of "black mayonnaise" and can easily remove before dredging the Merritt Sands. One station in the southern wing of the turning basin was sampled to project depth previously without encountering Merritt sands. Instead, layers or material indicative of an abandoned drydock were encountered. since drydocks in the vicinity had been dredged to -50 feet MLLW during World War II, 
concerns were ratsed that dredging the area to -42 to -44 feet MLLW may uncover and leave exposed a highly contaminated valume of sediments. The Distrlet agreed to sample the subject area below project depths and, if as feared, the sediments are highly contaminated, consider removing those sediments during project construction to avoid potentially adverse enviranmental effects. The District will undertake subbottom profiling of the turning basin wings in order to better define the extent of the Merritt Sands and to delineate the exact location of any previously dredged areas.

6. The deepening of berthing areas in the Oakland Inner and outer flastors will be undertaken by the Port and is interdependent with the deepening of the channels. Accordingly, the environmental impacts of dredging and disposal of sediments from the berthing areas must also be addressed in the project SEIS. Sediments from the berths to be deepened will be sampled and evaluated as part of this program. The tentative sampling plan for the berths was discussed at the subject meeting and is presented as attachment $C$.

7. Prabably the most significant accomplishment of the subject meeting was the agreement of the experts from the respective agencies on the conduct of the sediment biosssays and the interpretation of the bioassay results for proposed aquatic disposal of project sediments. A summary is presented below:

a. Ninety six howr suspended particulate phase (spp) bioassays will be run in accordance with reference a. for composites of stations specified in reference c. Test organisms are to include larvae of aither the oyster (Crassostrea gigas) or the mussel (Mytilus edulus), juvenile crustacea (Holmesimysis sculpta), and juvenile, speckled sanddabs (citharichthys stigmaens). The results will be interpreted in accordance with the guidance (reference a).

b. Ten day, solid phase (Sp) bioassays will be conducted utilizing, at minimum, an infaunal amphipod (Rhepoxymius abronius), a burrowing polychaete (Nephthys caecoides), and a juvenile demersal flatfish (Citharichthys stigmaens). Three different organisms will be utilized in arder to provide phylogenetic diversity in the assays. Given that a test is valid in control environments, if mortality of the test organisms in the dredged material is not statistically greater than in the reference sediment, or does not exceed mortality in the reference sediment by greater than ten percentage points (fifteen percentage points for the amphipods), the dredged sediment complies with the benthic bioassay criteria of the applicable regulations. Compliance with benthic bioassay criteria in sediments where mortality is both statistically significant and exceeds the established percentage will be considered on a case by case basis. Note: bioaccumulation must also be considered regardless of toxicity exposure bioassays.

c. Twenty eight day bioaccumulation exposures will be run in accordance with the guidance and utilize the deposit feeding, bivalve mollusc (Macoma nasuta) and the burrowing polychaete (Nephthys caecoides). Prior to testing, and after twenty four hour depurations, 
an aliguot of test organisms will be analyzed to evaluate the mollusc (Macoma naruta) and the burrowing polychaete (Nephthys caecoides). Prior to testing, and after twenty four hour depurations, an aliquot of test organisms will be analyzed to evaluate the potential contamination of organisms to be tested. After exposure to sediments, the twenty lour hour depuration for the polychaetes will be accomplished in control sediments; depuration of the mallusas will not require sediments. In oxder to compensate for chemical loading from detrital food material in the guts of depurated polychaetes, the concentrations of observed chemicals in control organisms will be subtracted from levels abserved in organisms exposed to treatment sediments. Of course, all data and calculation will be shown in the respective report or appendices. Dredged material clearly complies with bioaccumulation criteria in the regulations when bioaccumulation of contaminants of concern in organisms exposed to the dredged material does not statistically exceed bioaccumulation in organisms exposed to the reference raterial. Compliance of dredged material when statistically significant bioaccumulation of contaminants of concern in tissues of organisms exposed to dredged materials exceeds bioaccumulation of contaminants in tissues of organisms exposed to reference sediments will be determined on a case by case basis considering the factors presented in reference a. (pages $6-6$ and $6-7$ ).

d. Abnormalities observed on livers of juvenile, speckled sand dabs (Citharichthys sticmaeus) after suspended particulate phase exposures to sediments from two Inner Harbor stations during the 1988 confirmatory testing or project sediments (reference d) have heightened concerns. Though sediments from those stations have been determined to be unsuitable for unrestricted ocean disposal and will not be retested in the proposed program, livers of sand dabs (c. stacmaeus) subjected to solid phase exposures will be archived for possible future histopathologic examination.

8. Because the sediment evaluation program for the Oakland Harbor Navigation Improvement Project must proceed before selection of a final disposal site or sites for the project, the testing program has been designed to be applicable for ail aquatic alternatives and follows the guidance provided in references $a$ and $b$. The technical representative of the respective agencies readily agreed upon the regulsite reference sites for the comparative bioassay testing. A third ocean reference will be added to the program to represent the offshelf environment $(R \#-00)$. The offshelf reference will join the onshelf Pt. Reyes "coarse" and "fine" references (RH-OS $C$ and $R \#-O s ~ I)$. An expected and welcome change in the revised "Gold Book" will call for references representative of the disposal site environs prior to any dredged material disposal. A composite reference designed to be representative of conditions at Alcatraz as if dredged material disposal had not taken place (R\#-NC) is illustrated in Figure 1. We will, however, continue to collect an Alcatraz disposal site reference sediment ( $R \#-\mathrm{Na}$ ) until the new "Gold Book" is finalized. A sediment composite from the Bay Farm Island borrow area will comprise the third in-Bay reference (R\#-Nb). Details of references sites are presented in attachment $D$. 
9. A Waterways Experiment Station proposal to evaluate the potential bioaccumulation in oxganisms resulting from exposure to suspended sediments from the Oakland Harbor Navigation Improvement Project (reference e) was discussed. It was confirmed that each exposure in the FATES systom will include a deposit feeding bivalve mollusc (Macoma nasuta), a suspension feeding bivalve mollusc (Mvtilus edulis), and a fish, either the ecologically important shiner perch (Cymatogaster agcreotata) or the demersal, speckled sand dabs (Citharichthys stigmaeus) utilized in solid phase and suspended particulate phase toxicity exposures. Bioaccumulation results measured in the simulation will be evaluated in light of the factors presented in reference a, (pages 6-6 and 6-7) and a full discussion will be presented in the forthcoming SEIS. No pass/fail criteria were deemed appropriate Results will also be compared with results of solid phase bioacoumulation exposures utilizing the same sediments.

10. A plan to evaluate project sediments for placement in an upland enviranment was presented for comment Study elements include analysis of effluent, analysis of surface runoff (utilizing the WES rainfall simulator/soil bed lysimeter), analysis of leachate, measurement of potential plant uptake of contaminants (in wES index plants cyperus esculentus, spartina alterniflora, and sporobolus virgintcus), and measurement of potential bioaccumulation in an earthworm (Eisenia foedia). Addition of toxicity testing of nunoef waters was suggested and has been added to the program. Three appropriate species (such as Daphnia sp. and Mysids so, will be utilized in laboratory exposures in accordance with suspended particulate phase bioassay protocols.

11. The 1986 Water Resources Development Act authorizing construction of the Oakland Harbor Project specifjes consideration of creating marshlands with project sediments. Accordingly, a plan to evaluate project sediments for potential marshland or wetland creation is required. Scientist at the Waterways Experiment station have proposed a standard WES bioassay procedure utilizing aquaria with simulated tides. Two different salinity regines, one tipical of san Francisco Bay waters and the other representative of the lower Sacramento-San Joaquin River Delta waters are to be evaluated. An appropriate plant species and three suitable intertidal organisms will be exposed to sediments for 28 days. Tissues will be measure to assay bioaccumulation.

12. Another Waterways Experiment Station study proposal, considering potential chronic effects of sediments in the aquatic environment, was the final project sediment evaluation stady discussed at the subject meeting. Details of the study are presented in reference $f$. It was agreed that a oultured polychaete (Neanthes arenaceodentata) was the most appropriate organism currently available for the study and that the existing demographic population model developed for $N$. arenaceodentata was an appropriate measure of effects based on the current "state of the art." We concurred that population growth less than one standard deviation (of the replicate values for a sediment) above zero will be cause for serious concern and would indicate potentially unacceptable effocts. Where we did not reach a consensus was whether statistically significant reduction in 
populatien growth was as ecologically important. We agreed to consider the matter further and work toward developing a consensus at the next meeting of the group.

13. The Port of Oakland was unable to send a technical representative to the second day of meetings. Consequenitly, after the last of the separate studies for evaluating project sediments had been presented, it fell to the District to convey the Port's misgivings regarding two of the proposed studies: the proposal to evaluate the potential bioaccumulation resulting from exposure to project sediments suspended in the water column (reference $e$ ) and the proposal to evaluate potential chronic effects of exposure to either bedded or suspended sediments (reference f.). Both sudies were proposed by District personnel and Waterways Experiment station scientists to address specific concerns that arose over proposed in-Bay disposal of Oakland Harbor sediments as presented in the 1988 Supplemental Environmental Impact statement for the project. Applicability of these NEPA studies for evaluating proposed ocean disposal of project sediments was viewed as an additional benefit by the District. Concerns of the port center on the nonstandard nature of the tests, the undetermined ecological significance of the study results, and the lack of agreed upon interpretive guidance. Port comments are provided as an attachment (Attachment E).

14. Another meeting before the next sampling episode was suggested to delineate the final sampling plan and to discuss outstanding issues. A meeting with the same participants was also suggested to discuss the site specific application of sediment evaluation results. The meeting with Mr. Norm Rubinstein of EPA's Office of Research and Development (ORD) was scheduled for 16 May 1990 at the Wicerways Experiment Station in order to expedite the requested ORD review the proposed work plan ("the first application of the new "Green Book").

15. A draft version of this memorandum was circulated to all the respective agencies for review and comment. comments and suggested revisions from respesentatives from the District, the USAE Waterways Experiment Station, Battelle Marine Sciences Laboratory, the Port of Oakland, and the San Francisoo Regional Water quality Control Board have been received. This final version of the menorandum has been modified and corrected according to the received comments. EPA Region 9 has not commented on the draft memorandum.

Brian Walls

Civil Engineer 


\section{CF:}

CESPN-DD(PM) (Farless)

CESPN-PE (Angeloni)

CESPN-PE-A (Rakstins)

CESPN-PE-P (Brodie, Guy, Kit)

CESPN-PE-R (Chisholm, Lemlich)

CESPN-PM (Dettle, Harari, Opton)

CEWES-ES-R (Dillon, Lee, MCFarland, Saunders)

EPA Region IX (Cotter, Liu, Oshida)

Port of Oakland (McGrath)

RWQCB (Carlin) 


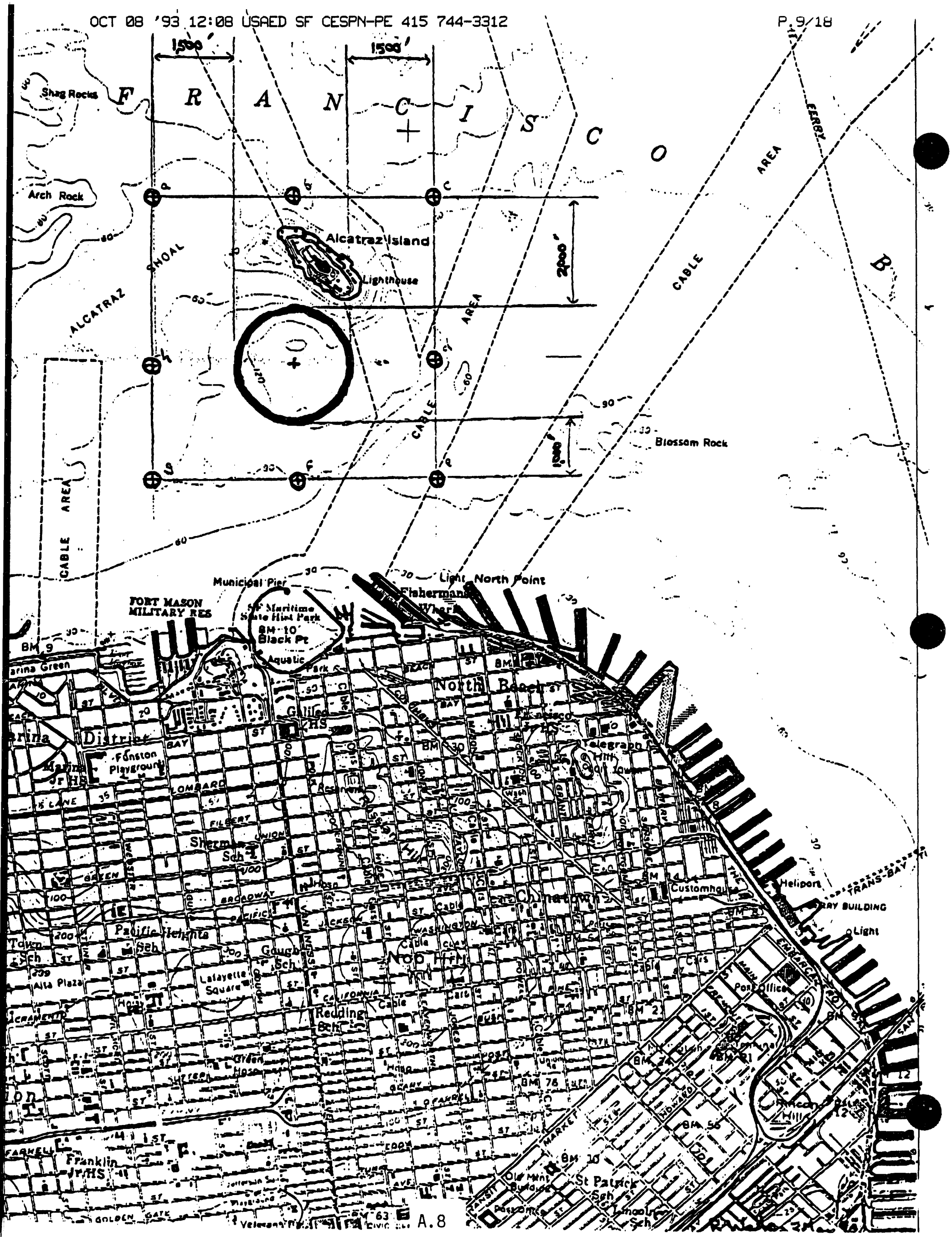


Attachment A

USACE/USEPA/RWQCB

Oakland Harbor Sediment Evaluation Program

Meetings of 10 - 11 May 1990

\section{ATTENDEES}

$\begin{array}{llr}\text { Michael Carlin } & \text { RWQCB } & 415-464-1325 \\ \text { Rod Chisholm } & \text { San Francisco District } & 415-744-3032 \\ \text { Susan Colman } & \text { Port of Oakland } & 415-272-1184 \\ \text { Patrlck Cotter } & \text { Region 9 } & 415-705-2162 \\ \text { Tom Dillon } & \text { Waterways Experiment Station } 601-634-3922 \\ \text { Roger Golden } & \text { San Francisco District } & 415-744-3344 \\ \text { Jake Harari } & \text { San Francisco District } & 415-744-3257 \\ \text { Dick Lee } & \text { Waterways Experiment Station } 601-634-3585 \\ \text { Ed Liu } & \text { Region 9 } & 415-705-2163 \\ \text { Sandra Lemlich } & \text { San Francisco District } & 415-744-3344 \\ \text { Victor MCFarland } & \text { Waterways Experiment Station 601-634-3721 } \\ \text { Jim MCGath } & \text { Port of Oakland } & 415-272-1175 \\ \text { Phil Oshida } & \text { Region 9 } & 415-705-2187 \\ \text { Lester Tong } & \text { South Pacific Division } & 415-705-1620 \\ \text { Brian Walls } & \text { San Franclsco District } & 4.5-744-3287 \\ \text { Jack Q. Word } & \text { Battelle Marine Science Lab } & 206-683-4151\end{array}$




\section{Attachment B}

USACE/USEPA/RWQCB

Oakland Harbor Sediment Evaluation Program

Meetings of 10 - 11 May 1990

\section{AGENDA}

Room 824; 211 Main street

San Francisco, CA

Introduction

Meeting objectives

Project background

Historic land use survey

other sources of contaminants

Previous testing

Evaluating sediments for Aquatic Disposal

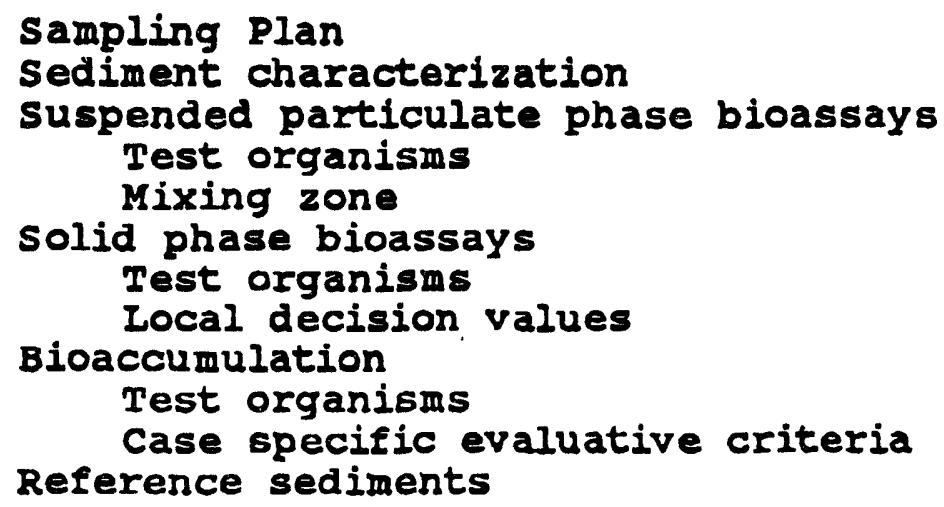

Evaluating potential suspended sediment Bioaccumulation

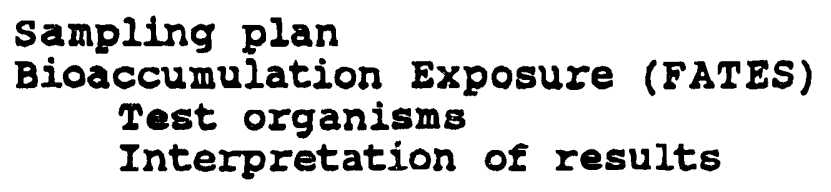

Evaluating sediments for Placement in an Upland site

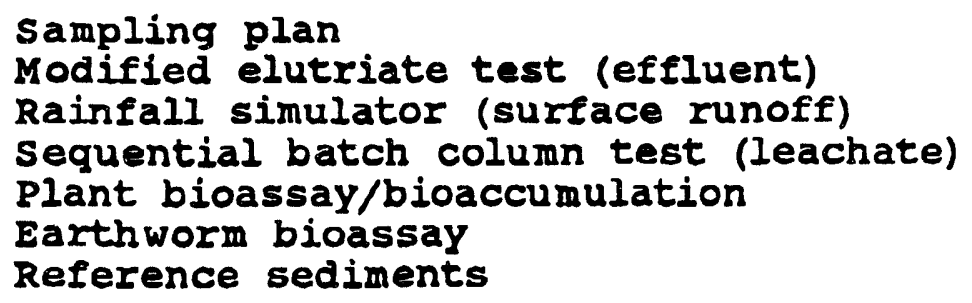


Attachment B, continued

Evaluating sediments cor Marshland/wetland creation

Sampling plan

Freshwater bioassay/bioaccumulation

Brackish water bioassay/bioaccumulation

saltwater bioassay/bioaccumulation

Evaluating Potential Chronic Effects

Sampling Plan

Simulation design

selection of sublethal endpoints

Test organisms

Nontreatment factors

Solid phase exposure

suspended particulate phase exposure

Bioaccumulation

Direct effects

Interpreting results

\section{Summary}

Comment

Meeting memorandum

schedule

Conclusion 


\title{
Attachment $\mathbf{C}$
}

\author{
USACE/USEPA/RWQCB \\ Oakland Harbor Sediment Evaluation Program \\ Meetings of 10 - 11 May 1990
}

\section{BERTHING AREA SAMPIING PROGRAM}

\begin{abstract}
I\#-B1 suspended particulate phase, solid phase, and bioaccumulation testing of a composite sediment from two stations $[I \#-\bar{B} 1$ (a) and I\#-BI(b)] in Berth $\# 60$, part of American President Iine's (API's) Inner Harbor terminal; possible organotin contamination; approximately 26,000 cubic yands of sediments, from -39 feet MLLW to -46 feet MLLW assuming 508 dredging of the two feet of allowed overdepth dredging.
\end{abstract}

I\#-B2 suspended particulate phase, solid phase, and bicaccumulation testing of a composite sediment from two stations [I\#-B2(a) and I\#-B2(b)] in Berth \#61, part of APL's Inner Harbor terminal; possible organotin contamination; approximately 30,000 cubic yards of sediments, from -39 feet MLLW to -46 feet MLLW assuming $50 \%$ dredging of the two feet of allowed overdepth dredging.

I\#-B3 Suspended particulate phase, solid phase, and bioaccumulation testing of a composite sediment frola two stations [I\$-B3(a) and I\#-B3(b)] in Berth \#62, part of APL's Inner Harbor terminal; possible organotin contamination; approximately 16,000 cubic yards of sediments, from -41 feet MILW to -46 feet MLIW assuming $50 \%$ dredging of the two feet of allowed overdepth dredging.

I\#-B4 suspended particulate phase, solid phase, and bioaccumulation testing of a composite sediment from two stations [I\#-B4(a) and I\#-B4(b)] in Berth \#63, part of APL's Inner Harbor terminal; possible organotin contamination; approximately 16,000 cubic yards of sediments, from -41 feet MLLW to -46 feet MLIW assuming 508 dredging of the two feet of allowed overdepth dredging.

I\#-B7 Suspended particulate phase, solid phase and bioaccumulation testing of a composite sediment from four stations [I\#-B] (a) to $B \#-7(d)]$ in Berths \#67 and \#68 serving the John F. Howard Inner Harbor terminals; sediments in areas adjacent to stations $B 7(a)$ and $B 7(b)$ have been found unsuitable for unrestricted ocean disposal; approximately 20,000 cubic yards of sediments, from -43 feet MIIW to -46 feet MLIW assuming $50 \%$ dredging of the two feet of allowed overdepth dredging.

O\#-BI Suspended particulate phase, solid phase, and bioaccumulation testing of a composite sediment from six stations [O\#-B](a) to O\#-BI(f) ] in the westerm half of Berth \#36 and Berths \#37 and \#38, serving the outer Harbor Seventh street terminal; the terminal was constructed with fill from excavation of the BART tunnel; significant contamination of sediments is not expected; approximately 58,000 cubic yards of sediments, from -41 feet MLLW to -46 feet MLWW assuming 50 dredging of the two feet of allowed overdepth dredging. 


\section{Attachment $c$, continued}

O\#-B4 suspended particulate phase, solid phase, and bioaccumulation testing of a composite sediment from six stations [O\#-B4(a) to $O \#-B 4(f)]$ in Berths \#31, \#32 and \#33, serving a new outer Harbor terminal (now under construction); approximately 96,000 cublc yards of sediments, from -39 feet MLIW to -46 feet MLLW assuming $50 \%$ dredging of the two feet of allowed overdepth dredging.

O\#-B6 suspended particulate phase, solid phase, and bioaccumulation testing of a composite sediment from six stations CO\#-B6(a) to $O \#-B 6(f)]$ in Berths \#24, \#25 and \#26, serving the outer Harbor Maersk Iine terminal and the Transbay Container terminal; approximately 36,000 cubic yards of sediments; from -43 feet MLLW to -46 feet for Berth $=24$ [stations O\#-B6(e) and O\#-B6(I)], from -39 feet MLLW to -46 feet MIIL for Berth \#25 [stations O\#-B6(C) and O\#-B6(d)], and frsm -41 leet MLLW to -46 feet MLLW for Berth \#26 [stations O\#-B6(a) and O\#-B6(b)] assuming $50 \%$ dredging of the two feet of allowed overdepth dredging.

O\#-B7 suspended particulate phase, solid phase, and bioaccumulation testing of a composite sediment from eight stations [O\#-B] (a) to 0 \#-B7(h)] in Berths \#20, \#21, \#22 and \#23, serving the outer Harbor Public terminal and the sea-Land terminal; approximately 38,000 cubic yards of sediments, from -43 feet MLLW to -46 feet MLIW assuming 508 dredging of the two feet of allowed overdepth dredging. 
USACE/USEPA/RWQCB

Oakland Harbor Sediment Evaluation Program Meetings of 10 - 11 May 1990

\section{AQOATIC TESTING PROGRAM SEDIMENT REPERENCES}

R\#-Na The Alcatraz disposal site reference called for in current
regulations and guidance; a composite of eight stations from
within the site, two each from the four quadrants.

R\#-Nb The Bay Farm Island Borrow Area reference sedinent; a composite of six to eight stations from the proposed disposal site.

R\#-NC The Central Bay - Alcatraz environs reference cediment supported by the technical representatives of the San Francisco District, Region 9, and the RWQCB and selected to comply with expected changes in the "Gold Book"; a composite of eight stations surmounding Alcatraz yet believed to be removed from influences of dredged material disposal at the site: station R\#-NC(a) 2500 feet west and 3000 feet north of the center of the Alcatraz Disposal site (site center), station R\#-NC(b) 3000 leet north of the site center, station R\#-NC(c) 3000 feet north and 2500 feet east of site center, station $\mathrm{R} \#-\mathrm{NC}$ (d) 2500 feet east of site center, station R\#-NC(e) 2500 feet east and 2000 feet south of site center, station R\#-NC(f) 2000 feet south of site center, station R\#-Nc(g) 2000 feet south and 2500 feet west of sice center, and station R\#-NC(h) 2500 feet west of site center.

R\#-Od Deep ocean disposal site reference selected to be representative of all deep ocean candidate disposal sites; on the 700-fathom contour near the southern boundary of the Gulf of the Farallones Marine Sanctuary; unlikely to be selected as the disposal site cue to likely measurable suspended sediments in water column at boundary of sanctuary if used for disposal; outside of known radioactive material, explosives, or chemical weapons disposal areas; $37^{\circ} 24^{\prime} \mathrm{N}, 123^{\circ} 15^{\prime} \mathrm{W}$.

$R \#-O S(c)$ and $R \#-O s(f)$

On shelf references; previously used as reference sediment in confirmatory testing for the Oakland Harbor Navigation Improvement project in 1988 and 1989; low levels of anthropogenic contaminants; both coarse and fine grained references collected from same vicinity (see accompanying illustration): has be referred to as the "Pt. Reyes reference" in publications. 


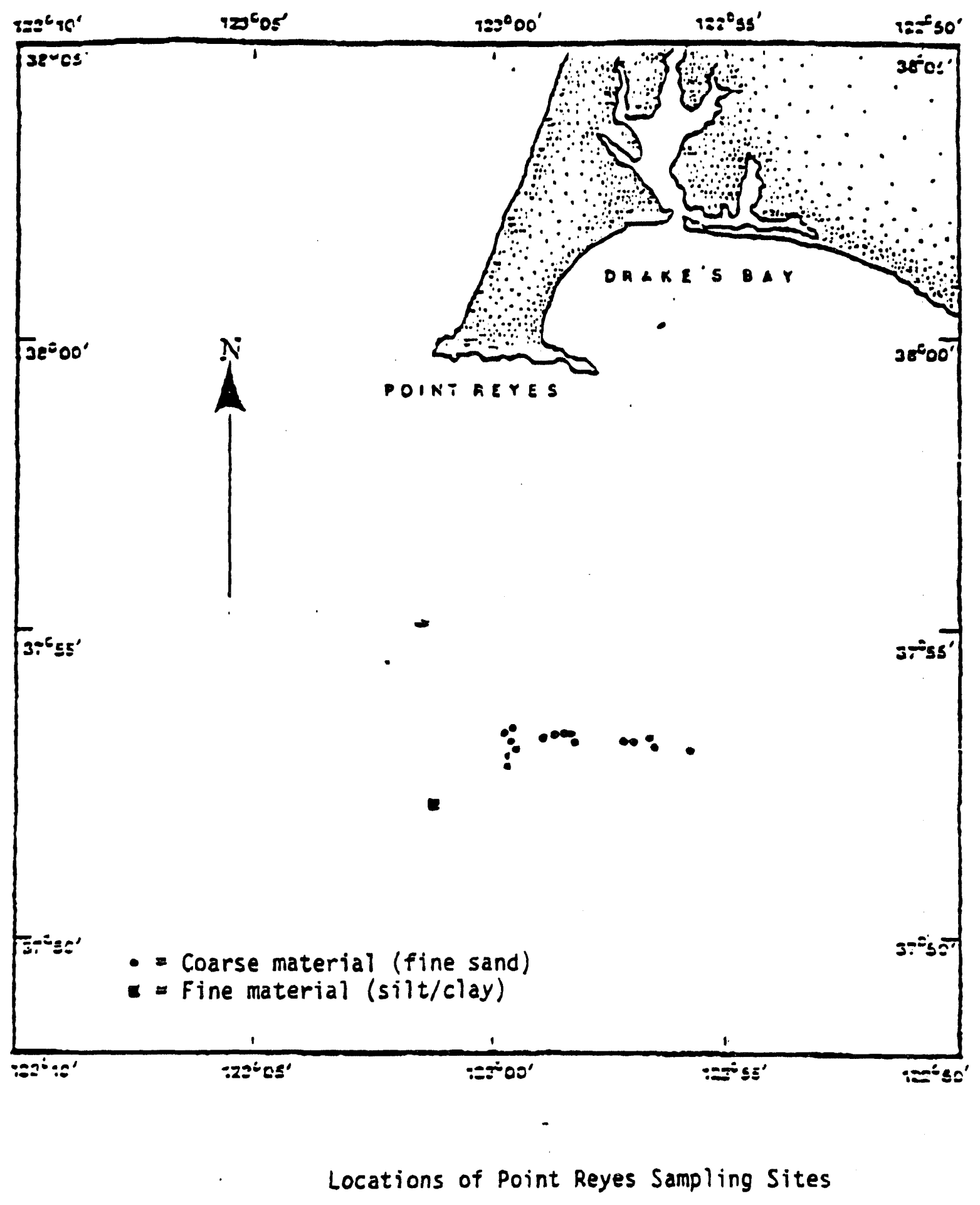

A. 15 


\title{
PORT OF OAKLAND
}

\author{
Monuow, Bner \\ novien \\ Caracesmonom \\ Anich \\ coctury 4 Hisems

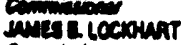 \\ conninginaw

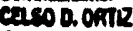

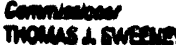 \\ Brian Wa11s \\ Brian Walls \\ May 21, 1990 \\ $\operatorname{lom}_{\operatorname{lom}} \operatorname{campla}$ \\ gineers \\ coverstions onter \\ tumes \& gearen \\ imanim arease. \\ Exesen w our \\ Exesu nour \\ Pon reming ind \\ andesment \\ San Francisco District \\ 221 main street \\ San Francisco, CA 94105 \\ Subject: Memorandum for the Record on May 10-11, 1990, meeting
on Sediment Testing \\ Dear Brian: \\ This letter is to confirm our discussions on the draft Memorandum \\ covering the subject meeting. As you know, the sediment Testing \\ program includes two studies that are of concern to the port of \\ bioaccumulation they have no clear standards: the FATES \\ bioaccumulation test, and the chronic effects test. The former \\ is essentially a research proposal. We discussed the need to \\ make clear in the Memorandum the fact that both tests are \\ intended for NEPA purposes, and to indicate some of the Port's
reservations about the tests. \\ Regarding the FATEs test, we remain concerned about \\ interpretation of bioaccumulation. Bloaccumulation could occur \\ unresolved questions about bioaccumulation in the field. I think \\ your Memorandum must make it clear that this test will only be \\ used as indicated in the Green Book, and is intended to establish \\ a comparison to the benthic bioaccumulation studies. It would be \\ helpful to note for the record the Iimitations of the test in \\ establishing whether or not bioaccumulation could be expected in \\ the field from the same sediments, or whether such \\ bioaccumulation would have ecological effects.
}


OCT 88 '93 12:12 USAED SF CESPN-PE 415 744-3312

We have similar reservations about the chronic effects test. The applicability of this test is even more remote as the test lacks the guidance given the bioaccumulation test in the Green Book. The port's reservations, and the applicability of the test to answering NEPA questions rather than to questions of disposal permitting, should be made clear in the final Memorandum.

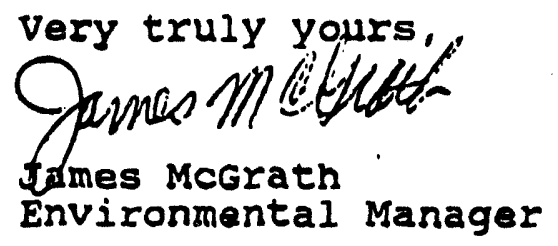

cc: Jack Farless, Charles Roberts, Neil Werner 
Distribution

No. of

copies

\section{QFFSITE}

2 DOE/Office of Scientific and

Technical Information

D. Roberts

U.S. Army Corps of Engineers

San Francisco District

211 Main Street

San Francisco, CA 94105

$5 \quad$ R. Chisholm

U.S. Army Corps of Engineers

San Francisco District

211 Main Street

San Francisco, CA 94105

J. Harari

U.S. Army Corps of Engineers

San Francisco District

211 Main Street

San Francisco, CA 94105

K. Guy

U.S. Army Corps of Engineers

San Francisco District

211 Main Street

San Francisco, CA 94105
No. of

Copies

\section{ONSITE}

\section{DOE Richland Field Office}

P.W. Kruger

A5-90

12 Pacific Nonthwest Laboratory

D. K. Shreffler

R. M. Thom

J.Q. Word

R. M. Ecker

L.M. Gully

Publishing Coordination

Technical Report Files (5)

SEQUI

SEQUI

SEQUI

SEQUI

SEQUI

K1-06

Routing

M.J. Graham

K6-78

P.M. Irving

C.S. Sloane

P.C. Hays (last)

K6-98

K6-04

K6-86

Distr.1 

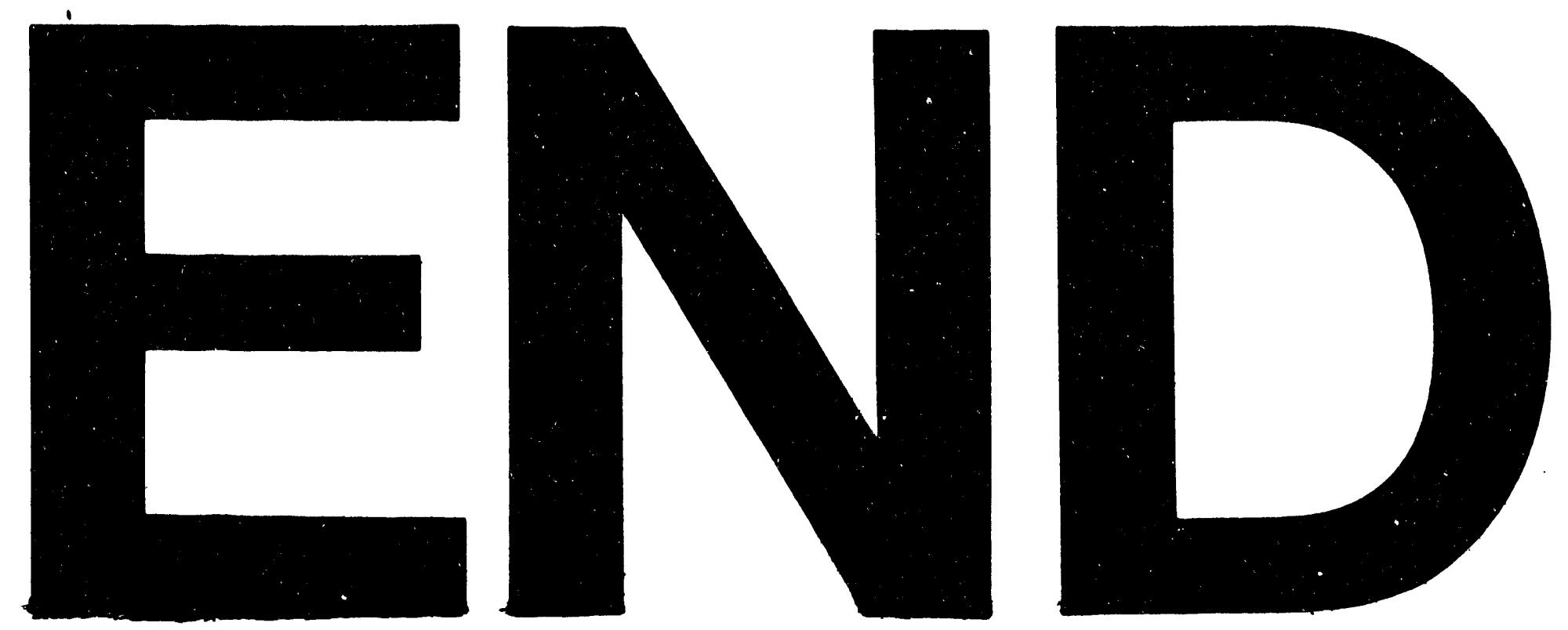

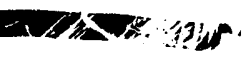

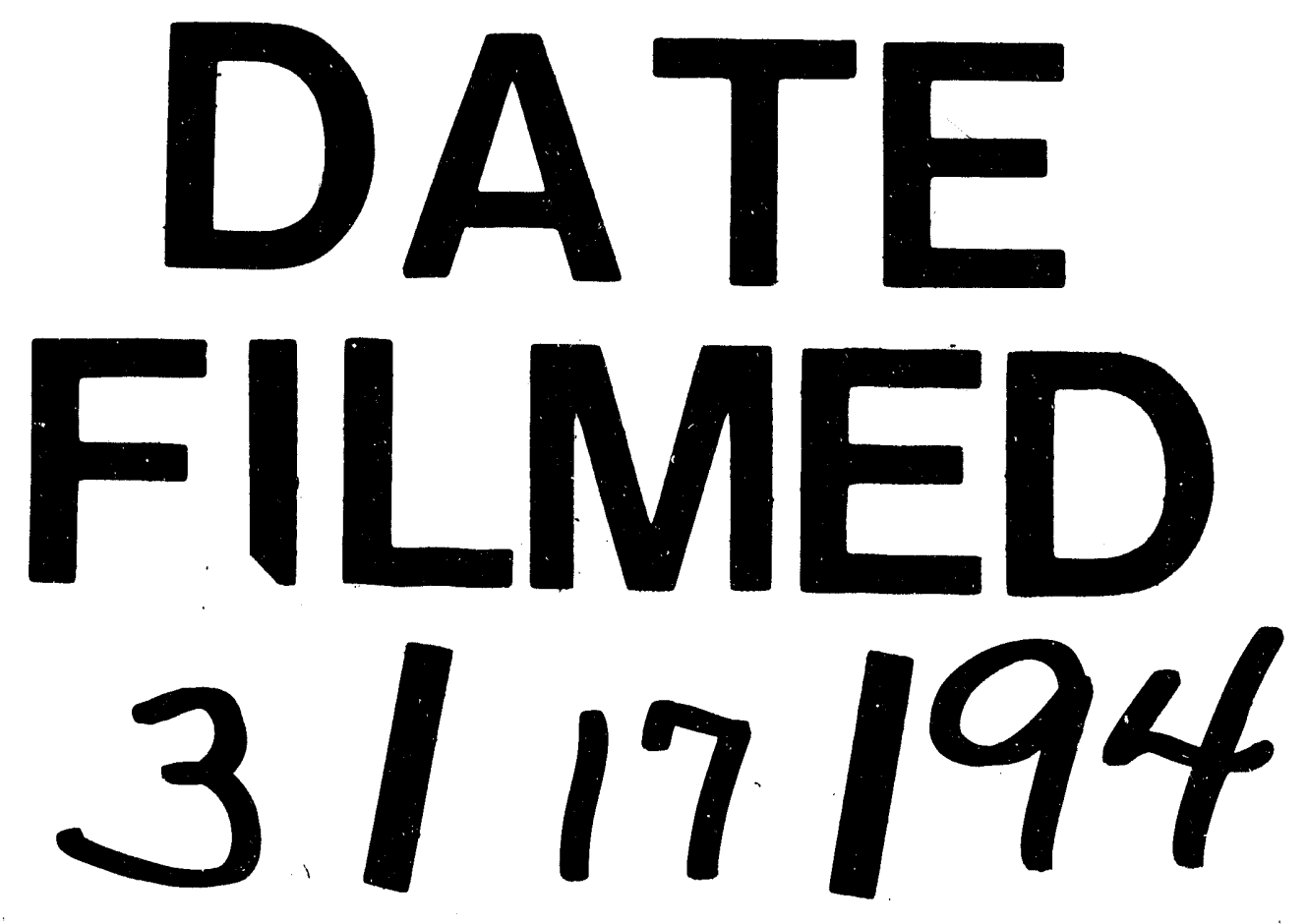


